\title{
sciendo
}

\section{Nutritional Recommendations for Physique Athletes}

\author{
by \\ Brandon M Roberts ${ }^{1}$, Eric $R$ Helms $^{2}$, Eric T Trexler ${ }^{3}$, Peter J Fitschen ${ }^{4}$
}

The popularity of physique sports is increasing, yet there are currently few comprehensive nutritional guidelines for these athletes. Physique sport now encompasses more than just a short phase before competition and offseason guidelines have recently been published. Therefore, the goal of this review is to provide an extensive guide for male and female physique athletes in the contest preparation and recovery period. As optimal protein intake is largely related to one's skeletal muscle mass, current evidence supports a range of 1.8-2.7 g/kg. Furthermore, as a benefit from having adequate carbohydrate to fuel performance and activity, low-end fat intake during contest preparation of 10-25\% of calories allows for what calories remain in the "energy budget" to come from carbohydrate to mitigate the negative impact of energy restriction and weight loss on training performance. For nutrient timing, we recommend consuming four or five protein boluses per day with one consumed near training and one prior to sleep. During competition periods, slower rates of weight loss ( $\leq 0.5 \%$ of body mass per week) are preferable for attenuating the loss of fat-free mass with the use of intermittent energy restriction strategies, such as diet breaks and refeeds, being possibly beneficial. Additionally, physiological and psychological factors are covered, and potential best-practice guidelines are provided for disordered eating and body image concerns since physique athletes present with higher incidences of these issues, which may be potentially exacerbated by certain traditional physique practices. We also review common peaking practices, and the critical transition to the post-competition period.

Key words: physique, bodybuilding, nutrition, contest preparation, competition recovery.

\section{Introduction}

Physique athletes are judged on aesthetics. Originally the name of the sport, bodybuilding is now one of many competitive classes under the umbrella of "physique competition" which have emerged over the past decade including men's physique, classic bodybuilding and several classes for females (Alwan et al., 2019). While recommendations for natural bodybuilders were previously published by Helms et al. in 2014 (Helms et al., 2014), research has grown at a rapid rate, including an increase in the number of studies on females. Contest preparation has become longer than in the past, with a focus on the postcompetition phase transition. For example, the length of contest preparation and recovery has increased from four months in the 1980s and 1990s (Bamman et al., 1993), to eight months or more in recent case studies (Pardue et al., 2017). Recently, offseason recommendations for physique competitors were published by Iraki and Colleagues (Iraki et al., 2019). Therefore, the goal of this review is to provide a comprehensive, evidence-based guide for male and female physique athletes with a focus on the contest preparation period from nutrition and supplement recommendations, to physiological and psychosocial adaptations, as well as best practices for peaking and postcompetition recovery.

\footnotetext{
1 - The Strength Guys, Birmingham, USA.

2 - Auckland University of Technology, Sports Performance Research Institute New Zealand, Auckland, New Zealand.

3 - Trexler Fitness LLC, Raleigh, USA.

4 - FitBody and Physique LLC, Stevens Point, USA.
} 


\section{Methods}

The electronic databases PubMed, SPORTDiscus, Google Scholar, and MEDLINE were searched. Each author was responsible for a section of the manuscript. The publications found were screened by each author responsible for a section. Long-term human studies were primarily selected, acute studies were accepted when directly relevant, and animal studies were used to help determine mechanisms when no such human research was available. Authors cross-checked one another's sections twice during the draft phase to ensure accurate interpretation of the included studies and appropriate scientific rationale behind recommendations. Since this review is an expanded and updated evidence-based guide, a narrative review style was chosen.

\section{Nutrition}

While preparing for competition, the goal of physique athletes is to maintain lean muscle mass while decreasing body fat. Contest preparation can last for 4 months or more during which calories are reduced and exercise is increased or maintained (Helms et al., 2014; Kistler et al., 2014; Pardue et al., 2017; Rossow et al., 2013). A recent review reported male bodybuilders consumed $\sim 3800$ calories per day and females consumed 2000 during non-competition phases (Spendlove et al., 2015). Yet, in the competition phase calories can be as low as $~ 1600$ for both sexes (Chappell et al., 2018; Halliday et al., 2016; Robinson et al., 2015). Total caloric recommendations for individuals vary widely, therefore we will focus on macronutrient ranges relative to body weight or overall percentages.

\section{Macronutrient intake}

Protein

Protein plays a critical role in physique sport. Meta-analytic data support mean intake of $\sim 1.6 \mathrm{~g} / \mathrm{kg} /$ day to maximize fat-free mass gains with resistance training; importantly, these data had an upper confidence interval of $2.2 \mathrm{~g} / \mathrm{kg} /$ day (Morton et al., 2018), which agrees with the upper confidence interval $(\sim 2.2 \mathrm{~g} / \mathrm{kg} /$ day $)$ in a group of male bodybuilders using the indicator amino acid oxidation method (Bandegan et al., 2017). Recent work in aspiring female physique athletes has also indicated that higher relative to lower protein diets ( $2.5 \mathrm{~g} / \mathrm{kg} /$ day vs. $0.9 \mathrm{~g} / \mathrm{kg} /$ day) increase lean body mass in the non-competition phase (Campbell et al., 2018). According to a recent review, physique athletes generally exceed these recommendations with males consuming 2-4 g/ $\mathrm{kg} /$ day and females 0.8-2.8 g/kg/day (Spendlove et al., 2015). Another study reported ranges of 2.7-3.3 g/kg/day in competitors (Chappell et al., 2018); ultimately, it seems physique athletes easily meet and often exceed protein recommendations.

Muscle protein synthesis (MPS) is often used as a surrogate of how protein intake or exercise affects muscle mass accrual. Physique athletes are in a caloric deficit during competition preparation, which in other populations decreases basal MPS by 27\% after only 5 days and 19\% after 10 days (Areta et al., 2013; Pasiakos et al., 2010). Furthermore, there are data specifically in lean individuals indicating muscle protein breakdown (MPB) is elevated as early as 10 days into a caloric deficit (Carbone et al., 2014). The combination of reduced MPS and increased MPB results in a negative net protein balance, which could be attenuated with high protein intakes. However, there are very few studies, observational or intervention-based, comparing high and low protein intake in athletes during a caloric deficit (Campbell et al., 2018; Helms et al., 2015; Longland et al., 2016; Walberg et al., 1988). For example, a recent study found that over a 4 -week period, a $40 \%$ caloric deficit with $2.4 \mathrm{~g} / \mathrm{kg} /$ day of protein per day resulted in more LBM preservation and more fat mass loss compared to a group consuming 1.2 $\mathrm{g} / \mathrm{kg} /$ day (Longland et al., 2016). This and previous data suggest higher protein consumption during a caloric deficit may be advantageous (Campbell et al., 2018; Helms et al., 2014; Longland et al., 2016; Walberg et al., 1988).

Protein has other important roles for physique athletes such as inducing fullness and satiety. A recent meta-analysis found higher protein meals increase acute ratings of fullness (Dhillon et al., 2016). In fact, in an energy deficit of 7 days, $2.9 \mathrm{~g} / \mathrm{kg} /$ day of protein resulted in less cravings than $1.8 \mathrm{~g} / \mathrm{kg} /$ day (Roberts et al., 2018). In a pilot crossover study on resistance-trained athletes, lower stress, mood disturbance and diet related stress were reported during the high protein $(2.8 \mathrm{~g} / \mathrm{kg} /$ day $)$ compared to the moderate protein (1.6 g/kg/day) phase (Helms et al., 2015). Taken together, consuming a high protein diet may help physique athletes increase satiety, reduce hunger, and mitigate stress.

When assessing protein recommendations 
for athletes from various research groups, there is a converging range from $1.6-2.7 \mathrm{~g} / \mathrm{kg} /$ day of protein (Hector and Phillips, 2018; Helms et al., 2014; Jager et al., 2017; Morton et al., 2018; Stokes et al., 2018). Since there is currently little evidence that high protein intake negatively impacts health in non-clinical populations, we recommend 1.8-2.7 $\mathrm{g} / \mathrm{kg} /$ day, or up to $3.5 \mathrm{~g} / \mathrm{kg} /$ day for those specifically attempting to mitigate hunger, so long as such high intake does not displace fat or carbohydrate in the diet to a degree that it impairs performance.

\section{Carbohydrate}

Carbohydrates are consumed by physique athletes to maintain training performance and help recovery post-training. A systematic review of dietary intake in bodybuilders reported large variability in carbohydrate intake with males consuming 243-637 g/day (3-7.2 g/ $/ \mathrm{kg})$, and females $160-415 \mathrm{~g} /$ day $(2.8-7.5 \mathrm{~g} / \mathrm{kg})$ (Spendlove et al., 2015). In a recent comparison of macronutrient to strict-dieting competitors, males consumed $\sim 323 \mathrm{~g}$ and females $\sim 218 \mathrm{~g}$ per day during the noncompetition phase (Ismaeel et al., 2018). Another study on men's physique athletes compared dietary intake in the cutting versus bulking phases. They found during the bulking phase participants consumed $\sim 261 \mathrm{~g}(2.98 \mathrm{~g} / \mathrm{kg})$ and $\sim 178 \mathrm{~g}(2.3 \mathrm{~g} / \mathrm{kg})$ in the cutting phase (Lenzi et al., 2019). Finally, in a recent study of contest preparation, males reduced carbohydrate intake (on average) from 4.4 to $4.1 \mathrm{~g} / \mathrm{kg}$ and females from 3.9 to $3.3 \mathrm{~g} / \mathrm{kg}$ (Chappell et al., 2018). An interesting observation in this study was that carbohydrate intake remained comparatively elevated $(5.1 \mathrm{~g} / \mathrm{kg})$ among males who placed higher (Spendlove et al., 2015). Cumulatively, these data indicate there is a wide range of carbohydrate intake typically consumed by physique athletes.

Previous publications recommended 4-7 $\mathrm{g} / \mathrm{kg}$ for bodybuilders (Slater and Phillips, 2011), which aligns with observational ranges seen in the literature. This range also allows room for individual differences. Yet, athletes attempting to achieve extremely lean conditions may, at least in a certain phase of preparation, need to consume less than $4 \mathrm{~g} / \mathrm{kg}$. Therefore, we recommend carbohydrate intake should be adjusted so that training performance is optimized while consuming adequate caloric intake to reach the desired physique. A realistic range for physique athletes that covers potential phases requiring very low energy intake to reach the desired level of leanness is $2-5 \mathrm{~g} / \mathrm{kg}$ per day. To improve satiety during low carbohydrate (and subsequently low energy) phases, we recommend the majority of carbohydrates come from whole grains, fruits, and vegetables while avoiding higher energy-density sources (Holt et al., 1995; Rolls et al., 1998; Zhang et al., 2018).

Fat

Previous recommendations for dietary fat intake for bodybuilders were $15-20 \%$ of total calories (Helms et al., 2014; Lambert et al., 2004). Indeed, in observational studies, physique athletes fall within this range. A systematic review reported fat intake among males was 19-241 g/day (8-33\% of calories) and from $9-124 \mathrm{~g} /$ day (9-35\%) among females (Spendlove et al., 2015). A case study of a male bodybuilder in competition preparation reported maintenance of fat intake at $0.7 \mathrm{~g} / \mathrm{kg}$ over the course of the study yet the percentage of calories from fat decreased from 29 to $21 \%$ (Pardue et al., 2017). Another study reported a female competitor's intake of $0.35 \mathrm{~g} / \mathrm{kg}(15 \%)$ during the final 10 weeks of the contest phase (Petrizzo et al., 2017). Furthermore, a cross-sectional study reported similar starting points of fat intake $(0.8$ $\mathrm{g} / \mathrm{kg}$ ) for both sexes, with only a small reduction at the end of contest preparation among females (0.6 $\mathrm{g} / \mathrm{kg}$ ) (Chappell et al., 2018). Absolute fat intake in other studies of competitive bodybuilders was reported around 40-65 g/day in some cases (Mitchell et al., 2017a; Suryanarayana et al., 1969) and 79-90 g/day in others (Mitchell et al., 2018). Cumulatively, these data indicate physique athletes, again, have fat intake that vary widely across individuals and phases which occasionally fall outside previously recommended ranges.

Dietary fat is often the last macronutrient of concern for physique athletes since protein and carbohydrates help build and preserve lean body mass, increase satiety, and aid training performance. While there is evidence in other populations suggesting dietary fat and testosterone levels are correlated (Sallinen et al., 2004; Volek et al., 1997), recent findings in bodybuilders suggest this relationship is likely due to energy availability rather than fat intake specifically. For example, a case-study of a male bodybuilder demonstrated a $72 \%$ decrease in testosterone while minimal relative changes in fat 
intake occurred (Pardue et al., 2017). These data and others (Maestu et al., 2010) suggest changes in the hormonal milieu may be inevitable when preparing for a physique competition. Furthermore, it is problematic extrapolating physiological changes in obese subjects to those who are lean. There is also a lack of interventional studies of dietary fat and the impact on hormone levels in physique athletes, which makes it difficult to understand how fat intake could affect their physiology (Heni et al., 2014; Suryanarayana et al., 1969).

Dietary fat intake of $20-35 \%$ has been previously recommended for athletes with a lower level of $15-20 \%$ for bodybuilders (Helms et al., 2014; Lambert et al., 2004). However, it is unlikely all individuals will be able to stay within this range during contest preparation since levels as low as $\sim 9 \%$ have been reported in the literature (Spendlove et al., 2015). Protein and carbohydrate should be prioritized for muscle retention, performance and satiety, and we therefore recommend fat intake of $10-25 \%$ to allow for individual variability and dietary flexibility yet we caution strongly against very low fat intake for long periods (Helms et al., 2014).

\section{Nutrient Timing}

In the context of physique athletes, "nutrient timing" can be discussed in relation to the number, timing and macronutrient composition of meals consumed in proximity to training, sleep, and one another. For example, bodybuilders consume a mean of 6 daily meals (Chappell et al., 2018), which may be based on the concept that frequent protein consumption translates to greater anabolism, more complete digestion, and/ or greater energy expenditure. In addition to the consumption of peri-workout protein, carbohydrate consumption is also a focus of physique athletes in the post-training period, as a way to both enhance the anabolic response to training and for rapid glycogen replenishment. Another long-employed strategy in physique circles is consuming slow-digesting proteins (such as casein) prior to sleep to prevent an extended catabolic period. However, this has only recently been studied by sports scientists (Res et al., 2012). The potential merits of each of these strategies are discussed in this section.
Protein Dosage Per-meal and in the Post-training Period

During the postprandial period after a protein bolus, additional protein fails to increase MPS until sufficient time has passed - known as the "muscle full effect". Therefore, the even spread of protein servings over the course of the day is theorized to maximize the 24 hour MPS area under the curve (Atherton et al., 2010). However, the first protein dosing strategy to appear in the literature was consuming protein shortly following resistance training. This strategy was proposed to improve the efficiency of skeletal muscle repair and remodeling as peak MPS rates are higher when protein is consumed in the post-training period (Tipton et al., 1999); however, a "threshold" leucine dose must be consumed for this to occur (Rieu et al., 2006). Researchers examined peri-workout protein boluses in multiple investigations to determine the dose needed to maximize MPS (Macnaughton et al., 2016; Moore et al., 2009; Witard et al., 2014). Following lower-body resistance exercise, a $20 \mathrm{~g}$ dose of egg protein stimulated MPS to a greater degree than smaller doses of $5 \mathrm{~g}$ or $10 \mathrm{~g}$, and a plateau occurred at a larger dose of $40 \mathrm{~g}$ (Moore et al., 2009). A similar outcome was observed in another study, in which $20 \mathrm{~g}$ whey protein resulted in a maximal stimulus following lower body resistance training, without a greater increase when $40 \mathrm{~g}$ was consumed (Witard et al., 2014). However, when performing whole-body resistance exercise rather than lower body only, $40 \mathrm{~g}$ of whey produced a significantly higher MPS response compared to $20 \mathrm{~g}$ (Macnaughton et al., 2016). Thus, when greater amounts of muscle mass are exposed to a stimulus, greater intake of protein is likely required to optimize adaptation. Given these acute findings, one would speculate that the specific timed dose of protein in relation to the volume of training would be a critical aspect for longitudinal hypertrophy. However, despite consistent short-term findings of enhanced MPS when protein is consumed in the post-training period, authors of a 2013 metaanalysis reported no significant effect on hypertrophy when controlling for total daily protein intake in longitudinal studies, regardless of timing (Schoenfeld et al., 2013).

Protein Spacing and Pre-sleep Consumption Interestingly, a similar disconnect between acute and chronic data exists in protein 
distribution research. For example, in a 12 hour tracer study of MPS, the area under the curve was highest when four $20 \mathrm{~g}$ whey protein doses were consumed every three hours versus two $40 \mathrm{~g}$ doses six hours apart, and eight $10 \mathrm{~g}$ doses every hour and a half (Areta et al., 2013). Theoretically, given the "muscle full effect" post protein-feeding which creates a "refractory period" during which additional protein cannot further enhance MPS (Atherton et al., 2010; Moore et al., 2009), a physique athlete should therefore reach, but not exceed, this dose every few hours after the refractory period ends to maximize longitudinal gains in muscle mass. Yet, in a 2018 systematic review of protein supplement distribution, the authors noted similar fat free mass changes between individuals consuming fewer protein servings of a high dose compared to those consuming more protein servings of a moderate dose (Hudson et al., 2018).

Likewise, this disconnect has also been observed when comparing short term and longitudinal night-time protein feeding studies. The first investigation of the acute response to presleep casein consumption was performed in 2012 (Res et al., 2012). The researchers reported that compared to a placebo, a $40 \mathrm{~g}$ dose of casein enhanced protein balance to a greater degree during sleep, which was subsequently replicated (Kouw et al., 2017; Trommelen et al., 2018). In the first long-term study, researchers observed greater muscle mass and strength increases in a group consuming protein before going to bed, compared to a group consuming a placebo (Kouw et al., 2017). Importantly, in this study total protein was unmatched. While the placebo group consumed $1.3 \mathrm{~g} / \mathrm{kg}$ in the 24-hour period, the proteinsupplemented group consumed $1.9 \mathrm{~g} / \mathrm{kg}$ (Morton et al., 2018). Contrasting this finding, in the only two 24-hour protein matched studies comparing long-term outcomes between casein night-time supplementation and groups consuming casein earlier in the day, significant between group differences were not reported (Antonio et al., 2017; Joy et al., 2018).

The explanation of why disparate outcomes are observed between short-term hypertrophy-proxy analyses (MPS) and long-term protein distribution studies examining body composition, is likely due to the methods utilized in MPS tracer studies. Specifically, participants are often provided only protein powder, fasted, measured over hours, and are typically provided whey which is a fast digesting protein. Thus, initial amino acid levels are lower, digestion is faster, and amino acid delivery is quicker. These lab-based digestion and amino acid kinetics differ substantially from "free-living" conditions when protein is consumed from whole foods, multiple times per day, in combination with other foods, which slows digestion and subsequent amino acid delivery. Indeed, in the "real world", amino acids may often be available at any given time point (Schoenfeld and Aragon, 2018). Pre-sleep protein research also shares some of these lab-specific limitations. As an example, an elevation in MPS lasts at least six hours (the entire time period studied) after consumption of lean steak providing $26 \mathrm{~g}$ of protein (Pennings et al., 2013); yet $26 \mathrm{~g}$ is only slightly more than one-third the protein in an average US dinner (Kim et al., 2016). Furthermore, the typical US dinner takes longer to digest not only because of the higher protein content, but due to the addition of other nutrients which would further delay digestion such as fiber and dietary fat (Schoenfeld and Aragon, 2018). Despite the limitations inherent to short term tracer studies, and the lack of theoretical proof in long term studies of muscle gain, from a physique perspective there is nothing to be lost and only a potential for gain by implementing a meal schedule which adheres to what would theoretically maximize the daily MPS area under the curve.

To conclude with an example in line with our protein recommendations, a physique athlete consuming $3 \mathrm{~g} / \mathrm{kg}$ of protein could eat four meals containing $0.75 \mathrm{~g} / \mathrm{kg}$ or five meals containing 0.6 $\mathrm{g} / \mathrm{kg}$ per day. Furthermore, the physique competitor could simply ensure they consumed one meal 1-2 hours prior to sleep with protein from a non-whey protein source, and finally, that one of their meals occurred within 1-2 hours before and after training.

Meal Frequency Effects on Body Composition, Appetite and Energy Expenditure

Physique athletes seeking muscle gain in the offseason eat comparable amounts to the high end of what Olympic athletes often consume (Spendlove et al., 2015). As the goal is not only to fuel performance, but to increase muscle mass between competitive seasons, a large volume of 
food is consumed to achieve an energy surplus. The observation that bodybuilders consume 6 meals per day on average (Chappell et al., 2018) may be a function of practicality, rather than a reflection of physiological necessity or optimality. While longitudinal data have not borne out the efficacy of manipulating the frequency of proteinfeedings to enhance hypertrophy, smaller more frequent eating occasions may theoretically aid the digestive process in the offseason and in clinical sports nutrition texts they are recommended as more feasible than simply eating more at existing meals (Dean and Burke, 2006). Indeed, greater hunger and desire to eat is reported by those consuming more frequent, smaller meals (Perrigue et al., 2016), and a moderate association between meal frequency and total energy intake is reported among elite athletes (Burke et al., 2003). Yet, recent large-scale epidemiological data indicate more frequent feedings $(>3)$ are associated with increases in the BMI (Kahleova et al., 2017). Furthermore, the existing meta-analyses and reviews of meal frequency interventions do not support an association between higher meal frequencies and fat loss, improved metabolic health or increased energy expenditure (Hutchison and Heilbronn, 2016; Raynor et al., 2015; Schoenfeld et al., 2015). Therefore, we recommend physique athletes consume a moderate meal frequency with an even protein distribution.

\section{Peri-Workout Carbohydrate}

The rationale for consuming carbohydrate following, during, and prior to training for bodybuilders is to facilitate glycogen replenishment for future resistance training sessions, maintain intra-session performance, and fuel proximal resistance training bouts, respectively (Mitchell et al., 2017a). However, complete resynthesis can be achieved within 24 hours following glycogen depletion when ample carbohydrates are consumed (Jentjens and Jeukendrup, 2003) and bodybuilders do not typically train the same muscle groups on subsequent days, such that performance would be impacted by glycogen depletion (Hackett et al., 2013). Indeed, most bodybuilders train each muscle group 1-2/week (Hackett et al., 2013). Furthermore, only $24-40 \%$ of muscle glycogen is depleted during standard volumes of resistance training (MacDougall et al., 1999; Tesch et al., 1986). To conclude, training performance in subsequent sessions is unlikely to be impaired if carbohydrates are not consumed in the post workout period, and hypertrophy is also not likely to be enhanced by the additional consumption of carbohydrate alongside post-workout protein, as insulin rises to adequate levels to fully suppress MPB via the consumption of amino acids alone (Aragon and Schoenfeld, 2013; Helms et al., 2014).

Glycogen is not the only mechanism by which carbohydrate intake could enhance or preserve resistance training performance when consumed near a training bout. Indeed, no greater effect on performance was observed after consuming a diet containing $7.7 \mathrm{~g} / \mathrm{kg} /$ day of carbohydrate for 48 hours compared to only 0.37 $\mathrm{g} / \mathrm{kg} /$ day when 15 sets of 15RM lower-body exercise were performed (Mitchell et al., 1997). Given this finding, it seems the body is capable of maintaining adequate glycogen in the face of carbohydrate restriction via metabolic conversions of other substrates (Volek et al., 2016), which is sufficient to sustain resistance training performance if ample calories are still consumed. However, in the context of a calorically restricted diet, there is evidence that lower carbohydrate intake can impair bodybuilding performance (Walberg et al., 1988) and that consumption of carbohydrates prior to training may improve it (Dudgeon et al., 2017). For example, one study found consumption of carbohydrate after an overnight fast resulted in the performance of greater training volumes compared to water (Bin Naharudin et al., 2019), although subjects were habitual breakfast eaters, which may have impacted the results. Furthermore, positive outcomes may be unrelated to muscle glycogen levels, and rather a result of stabilization of blood glucose, or perhaps liver or brain glycogen replenishment, or a central effect on delaying or reducing fatigue.

Some (Bastos-Silva et al., 2019; Decimoni 2018), but not all studies (Clarke et al., 2015; Dunkin and Phillips, 2017; Painelli et al., 2011) show that carbohydrate mouth rinsing can increase resistance training volume or delay fatigue (Bazzucchi et al., 2017). However, aggregate findings are inconsistent, and the exact mechanisms are elusive. Thus, further exploration of the effect of peri-workout carbohydrate intake for the purposes of enhancing bodybuilding training performance is needed. With that said, 
mouth rinsing provides a unique potential for dieting physique athletes to enhance performance via carbohydrate, without additional energy consumption.

In total, insufficient evidence exists to strongly state that pre-, intra- or post-training carbohydrate consumption enhances resistance training performance or hypertrophy; however, it seems prudent that physique athletes consume a meal containing easily digestible carbohydrate within $\sim 2$ hours prior to training to avoid any potential decrement to performance. Furthermore, there would be no harm in attempting a midsession mouth-rinse with a glucose-based drink as an attempt to maintain or improve performance during contest preparation, although future research is needed to confirm the efficacy of this practice.

\section{Supplements}

Dietary supplements appear to be a major component of the dietary strategies implemented by physique athletes. A recent study by Chappell et al. (2018) surveyed physique competitors on their nutrition habits in the months leading up to a natural bodybuilding competition. The authors noted the competitors routinely consumed between five and seven supplements during the contest preparation period; males averaged 7.0 supplements, whereas females 5.4. Protein powder was most commonly consumed, with survey results indicating $75.0 \%$ of males and $88.9 \%$ of females consumed them. Multivitamin supplements were used by $53.5 \%$ of males and $60 \%$ of females. The number of competitors using branched-chain amino acids (BCAAs), creatine, fat burners, individual amino acid supplements, preworkout supplements, and omega-3 fatty acids ranged from 39.4 to $49.4 \%$ in males, and 19.9 to $53.5 \%$ in females.

Protein powders are not inherently more efficacious than any other high-quality protein source and are generally viewed as a convenient means of accomplishing the previously discussed guidelines for protein intake. As such, protein supplementation will not be discussed in detail. Given the potential for diets to become restrictive late in contest preparation, ingestion of a wellformulated multivitamin supplement may be an effective strategy for ensuring suitable micronutrient intake, although efforts should be made to obtain sufficient nutrition from whole food sources. Given that multivitamins are a convenient means of obtaining nutrients that would otherwise be obtained from a wellstructured diet, multivitamins will not be covered in detail either. Rather, this section discusses the dietary supplements with the greatest potential to directly enhance competitive outcomes for physique athletes.

Creatine

Creatine is one of the most commonly used supplements among physique athletes. Daily endogenous creatine production is approximately one gram per day (Cooper et al., 2012), and omnivorous diets typically provide about 1-2 grams per day. Nonetheless, muscle creatine stores are generally only $60-80 \%$ saturated (Kreider et al., 2017). By supplementing with creatine, muscle storage of creatine and phosphocreatine are maximized, thereby delaying fatigue and enhancing performance. Creatine supplementation has been studied extensively, with results typically showing improvements in repetitive, highintensity exercise performance of up to $10-20 \%$, along with increased lean body mass when used in conjunction with resistance training (Kreider et al., 2017). To date, no legal dietary supplement has been shown to enhance resistance training performance as robustly and reliably as creatine, and both the International Society of Sports Nutrition (Kerksick et al., 2018) and the International Olympic Committee (IOC) (Maughan et al., 2018) list creatine in their top tier of evidence-based dietary supplements for performance enhancement. To increase intramuscular creatine storage to an ergogenic degree, loading protocols often involve ingestion of 20 grams of creatine per day (or approximately $0.3 \mathrm{~g} / \mathrm{kg}$ of body mass) divided between four equal doses, for approximately one week, followed by single daily maintenance doses of approximately five grams ( 0.07 to $0.1 \mathrm{~g} / \mathrm{kg})$. Alternately, evidence suggests that individuals who wish to bypass the loading stage can achieve ergogenic elevations in muscle creatine storage by consuming maintenance doses for approximately four weeks (Hultman et al., 1996). A large body of evidence suggests creatine is safe and well-tolerated with any gastrointestinal discomfort alleviated by splitting the total creatine intake into smaller doses (Ostojic and Ahmetovic, 2008). The most consistent side effect is an abrupt increase in body mass, 
typically in the range of $1-2 \mathrm{~kg}$. This initial weight gain is attributable to increased water retention due to the osmolytic nature of creatine; in theory, this fluid should largely be stored in the intracellular fluid compartment and should not substantially affect the outward appearance of the physique in a negative manner. Nonetheless, it would be prudent for physique athletes that are not creatine users to avoid a loading phase within the final 1-2 weeks prior to a competition.

Caffeine

Caffeine is a primary component of many pre-workout supplements and fat burners; thus, finding its way into two categories of common bodybuilding supplements. As such, Chappell et al. (2018) observed above-average daily caffeine intake in both male ( $322 \mathrm{mg} /$ day) and female (252 $\mathrm{mg} /$ day) physique athletes. The IOC recognized caffeine as one of the few dietary supplements with evidence supporting its capacity to directly improve exercise performance in a recent consensus statement (Maughan et al., 2018). While the early literature investigating performanceenhancing benefits of caffeine focused largely on endurance exercise outcomes (Costill et al., 1978), more caffeine research pertaining to strength and power has emerged in the last fifteen years. A meta-analysis published in 2018 (Grgic et al., 2018) indicated caffeine exerts a small, but statistically significant positive effect on maximal strength and power, such as one-repetition maximum and the vertical jump. There is also evidence that caffeine enhances muscular endurance (Grgic et al., 2019), which likely relates more closely to habitual training of physique athletes. Finally, the numerous physiological adaptations that accommodate energy restriction in lean athletes are likely to induce lethargy, hunger, and reduced energy expenditure. Caffeine use during contest preparation may confer benefits extraneous to its ergogenic effect by favorably affecting subjective the energy level, appetite, and energy expenditure (Harpaz et al., 2017). Taken together, current evidence would suggest that caffeine has the potential to directly improve performance for physique athletes. Dosing strategies often involve consuming a dose of $3-6 \mathrm{mg} / \mathrm{kg}$ of caffeine, approximately one hour prior to exercise (Maughan et al., 2018). Doses beyond 3-6 mg/kg do not appear to be more efficacious (Goldstein et al., 2010), and it should be noted that despite an acute lethal dose that is estimated to be around 10,000 $\mathrm{mg}$, it is often conservatively recommended that healthy adults restrict their daily caffeine intake to no more than roughly $6 \mathrm{mg} / \mathrm{kg}$ per day (Nawrot et al., 2003).

Nitric Oxide Precursors

Nitric oxide (NO) precursors, such as citrulline and dietary nitrate, are also common components of multi-ingredient pre-workout formulas. Nitric oxide is a gaseous cell signaling molecule with widespread effects throughout the body. As reviewed by Bailey et al. (2011), the potential mechanisms by which NO may enhance exercise performance include exercise efficiency, mitochondrial respiration, sarcoplasmic reticulum calcium kinetics, vasodilation, glucose uptake, and muscle fatigue (Bailey, 2011). Collectively, these exercise-related effects of $\mathrm{NO}$ have prompted interest in the potential ergogenic applications of ingredients that increase NO production. Due to the short half-life and poor stability of NO (Kelm, 1999), supplementation strategies for increasing NO production are restricted to supplementation with precursors of NO. In the nitric oxide synthasedependent (NOS-dependent) pathway of $\mathrm{NO}$ production, arginine is the direct precursor of NO. Unfortunately, arginine has relatively poor oral bioavailability (Schwedhelm et al., 2008), and exercise studies with arginine supplementation have largely yielded underwhelming results (Bescos et al., 2012). In contrast, citrulline has substantially greater bioavailability, and oral citrulline supplementation efficiently increases blood arginine levels (Schwedhelm et al., 2008). Perez-Guisado and Jakeman (2010) found citrulline enhanced repetitions to fatigue during resistance exercise. A recent meta-analysis (Trexler et al., 2019) reported a small, but significant effect of citrulline-based supplements for such outcomes. The exact mechanisms underlying the ergogenic effects of citrulline-based supplements are not entirely elucidated at this time. For resistance training studies, the most common dosing strategy yielding ergogenic effects involves consuming 8 grams of citrulline malate (presumably in a 2:1 citrulline to malate ratio), approximately one hour before exercise.

In an alternate pathway of NO production, dietary nitrate is reduced to nitrite, and further reduced to NO, in an NOS-independent manner (Bailey, 2011). In the past decade, a substantial 
body of literature reports inorganic nitrate and beetroot juice, a source of dietary nitrate, enhances endurance exercise capacity (McMahon et al., 2017). In contrast, few studies have evaluated the effects of nitrate on resistance exercise. Mosher et al. (2016) found six days of beetroot juice supplementation (containing $400 \mathrm{mg}$ nitrate per dose) enhanced bench press repetitions to fatigue over three sets taken to failure. Similarly, beetroot juice enhanced leg extension speed and power (Coggan et al., 2015), in addition to explosive force production in fatigued muscle (Tillin et al., 2018). These effects on muscle contractile function may relate to NO-induced increases in intracellular calcium concentrations and myofilament calcium sensitivity (Coggan and Peterson, 2018). Studies documenting ergogenic effects of nitrate tend to provide at least $400-500 \mathrm{mg}$ of nitrate $2-3$ hours prior to exercise, and chronic dosing strategies appear to enhance performance more reliably than acute supplementation. Furthermore, there is mechanistic evidence to suggest $\mathrm{NO}$ plays a permissive role in muscle hypertrophy by promoting satellite cell activation (Anderson, 2000). As such, the pharmacological blockade of endogenous NO production blunts hypertrophic adaptations to overloading in rats (Smith et al., 2002), and treatment with isosorbide dinitrate (an NO-donor) enhanced exercise-induced hypertrophy in mice (Leiter et al., 2012). Nonetheless, whether the findings from these mechanistic studies translate to healthy humans consuming NO precursor supplements is unknown. As a cautionary note, there is large variability in the dosing of beetroot in commercial supplements (Bailey et al., 2011). In summary, there are mechanistic justifications for the use of NO precursors by physique athletes, and preliminary studies suggesting beneficial effects on strength and power. However, more research is needed to draw definitive conclusions about the ergogenic applications of NO precursors, including citrulline and nitrate, for the purposes of enhancing resistance training performance and hypertrophy.

Beta-Alanine

As reviewed previously (Trexler et al., 2015), beta-alanine is the rate-limiting precursor to carnosine synthesis. When supplemented, betaalanine increases the intramuscular concentration of carnosine, which functions as an intracellular buffer. Proton accumulation occurs during highintensity exercise due to rapid ATP turnover. This proton accumulation leads to a local reduction in $\mathrm{pH}$, which is thought to contribute to fatigue and reduced capacity for force production. Baseline muscle carnosine concentrations vary depending on a number of factors including age, sex, training status, muscle fiber type distribution, and dietary habits, but beta-alanine supplementation has been shown to increase muscle carnosine by $64 \%$ after four weeks (Harris et al., 2006) and by $80 \%$ after ten weeks (Hill et al., 2007). Beta-alanine is recognized as an effective ergogenic aid by both the International Society of Sports Nutrition (Kerksick et al., 2018) and IOC (Maughan et al., 2018), but its effects vary based on the physiological demands of the exercise task tested. For example, a metaanalysis published in 2012 (Hobson et al., 2012) found the most pronounced effects were observed in exercise tests lasting 1-4 minutes. As a proton buffer, the ergogenic effects of beta-alanine are most pronounced for tasks requiring rapid ATP production via anaerobic glycolysis, such as highintensity continuous or intermittent bouts lasting 30 seconds to 10 minutes (Maughan et al., 2018). Based on the primary ergogenic mechanism, benefits could potentially be observed in programs with relatively high repetition ranges (Outlaw et al., 2016) or short rest periods between sets, although it remains unclear if beta-alanine promotes hypertrophy. One study found the combination of creatine and beta-alanine improved resistance training-induced hypertrophy significantly more than a placebo or creatine alone (Hoffman et al., 2006), whereas betaalanine failed to enhance increases in lean body mass in response to resistance training in other research (Outlaw et al., 2016). Nonetheless, it is possible that beta-alanine could be used to improve training adaptations by promoting greater training volume throughout the course of a resistance training program (Hoffman et al., 2008).

\section{Competition Preparation}

Length of Contest Preparation

Unfavorable physiological adaptations to weight loss in lean athletes are related both to absolute body fat levels and the magnitude of acute relative energy deficiency. By manipulating the length of contest preparation (and, therefore, the rate of weight loss), the size of the energy deficit can be modified to influence the degree of acute 
relative energy deficiency. For example, Mero et al. (2010) investigated the effects of two different rates of weight loss in recreationally trained females on protein-matched $(1.4 \mathrm{~g} / \mathrm{kg})$ diets. One group was assigned to lose $1 \mathrm{~kg}$ per week (with an energy deficit of $1100 \mathrm{kcal} /$ day), while the other was assigned to lose $0.5 \mathrm{~kg}$ per week (with an energy deficit of $550 \mathrm{kcal} /$ day). After the four-week intervention, the group with a faster rate of weight loss lost more weight and fat mass, but also experienced a significant reduction in testosterone and an increase in sex hormone binding globulin. Garthe and colleagues (2011) studied two rates of weight loss in elite male and female athletes. One group was assigned to lose $0.7 \%$ of their body mass per week (with a 19\% reduction in energy intake), while the other group was assigned to lose $1.4 \%$ per week (with a 30\% reduction in energy intake). In order to standardize the total amount of weight lost, the slow group spent longer duration of time in the weight loss phase than the fast group ( 8.5 versus 5.3 weeks, respectively). Both groups lost similar amounts of total body mass. However, the slow group lost significantly more fat mass than the fast group, and the slow group had a significant increase in lean mass while lean mass remained unchanged in the fast group. Regardless of group, females gained lean mass during the intervention; males in the slow group gained lean mass, whereas males in the fast group tended to lose lean mass. Furthermore, the slow weight loss group experienced more favorable changes in exercise performance.

In recent years, a number of case reports and small studies have documented contest preparation in male and female physique athletes. These studies have ranged from 14-32 weeks from the beginning of preparation to the first competition (Halliday et al., 2016; Kistler et al., 2014; Pardue et al., 2017; Robinson et al., 2015; Rohrig et al., 2017; Rossow et al., 2013; Tinsley et al., 2019). The loss of fat-free mass is a common observation among male physique athletes; all of the previously mentioned male case reports documented some degree of fat-free mass loss, with some as high as $6.6 \mathrm{~kg}$ (Kistler et al., 2014). Of the data available, duration of contest preparation does not appear to clearly dictate the degree of fatfree mass loss, as similar (and fairly substantial) losses have been reported in contest preparation periods as short as 14 weeks (Robinson et al., 2015) and up to 26 weeks (Kistler et al., 2014). It is difficult to determine ideal contest preparation duration using case reports, as the loss of fat-free mass is inevitably influenced by several factors, which include (but are not limited to) differences in overall weight loss, dietary approaches, resistance training approaches, volume of cardiovascular exercise, and genetic variability between individuals. Nonetheless, Chappell and colleagues (2018) noted that male competitors receiving high contest placings tended to implement a rate of weight loss of $0.46 \%$ of body mass per week, which was slower than the nonplacers, who lost over $0.5 \%$ of body mass per week. In contrast, case reports documenting comparatively higher losses of fat-free mass implemented weight loss rates of $0.7 \%$ (Kistler et al., 2014) and 1.0\% (Robinson et al., 2015) per week. As such, Chappell and colleagues (2018) speculate that slower weight loss may lead to more favorable placements by facilitating retention of fat-free mass. In female case reports, lean mass has remained stable (Halliday et al., 2016) or increased by up to $1.3 \mathrm{~kg}$ (Rohrig et al., 2017) over the course of preparation, with rates of weight loss generally ranging from 0.4 to $0.75 \%$ of body mass per week. A larger study (Hulmi et al., 2016) also found a slight increase in fat-free mass in female physique athletes $(+0.4 \mathrm{~kg}$, measured via DEXA) over the course of contest preparation, with average duration of 19.8 weeks. While research to date has not documented marked reductions in fat-free mass during contest preparation among females, unfavorable effects on performance, hormones, and menstrual status have been noted. Such unfavorable outcomes highlight the importance of carefully managing the magnitude of energy deficiency, but it is difficult to draw conclusions about ideal preparation duration due to homogenous approaches in the literature.

Taken together, the limited data indicate that rate of weight loss is more physiologically relevant than the duration of contest preparation per se, and slower rates of weight loss $(\leq 0.5 \%$ of body mass per week) are generally preferable for attenuating unfavorable adaptations to weight loss and losses of fat-free mass. Retention of fat-free mass appears to be a more pressing concern in male competitors than female competitors, which may relate to greater overall reductions in body mass, more drastic changes in testosterone levels, 
lower absolute and relative body fat percentage requirements for the male bodybuilding category, competitors being more experienced and closer to their genetic ceiling for muscle mass, and possibly additional factors.

Diet Periodization

While the rate of weight loss during contest preparation is often discussed as a linear weekly reduction in weight, the energy deficit is often applied in a nonlinear manner. Previous research has shown that bodybuilders frequently implement refeeds (Mitchell et al., 2017a) and cheat meals (Chappell et al., 2018), which both represent transient elevations in caloric intake for a fixed amount of time. In addition, many studies have investigated the implementation of diet breaks, in which individuals on a weight loss diet temporarily revert to ad libitum, self-selected eating habits (Keogh et al., 2014) or increase caloric intake to achieve neutral energy balance (Byrne et al., 2018). Carbohydrate restriction has the potential to reduce training capacity (Walberg et al., 1988), and intramuscular glycogen depletion has been shown to directly impair muscle function (Ortenblad et al., 2013). As such, high carbohydrate refeeds and cheat meals (or cheat days) may confer transient positive effects on training quality during a prolonged energy deficit. Cheat meals/days, refeeds, and diet breaks fall on a spectrum of nonlinear fat loss strategies, as presented in Figure 1. Such strategies also offer a psychological reprieve from the restrictive dietary constraints imposed during a weight loss diet, allowing the competitor to enjoy foods that may be too high in carbohydrate or caloric content to be regularly incorporated into the diet. However, given the prevalence of binge eating episodes among physique athletes discussed in subsequent sections, the practice of unstructured cheat meals or cheat days may be contraindicated in many circumstances. Aside from psychological factors, arguably the most intriguing application of nonlinear fat loss strategies for physique athletes pertains to the potential to mitigate some of the unfavorable physiological adaptations that accompany weight loss.

The physiological adaptations associated with contest preparation are related to both fat mass reduction and short-term energy availability. While fat mass reduction is a necessary goal of contest preparation, energy availability can be transiently manipulated. Leptin is reduced after only days of energy restriction (Keim et al., 1998), long before significant fat loss has occurred. This initial drop relates to short-term energy availability, and is particularly influenced by carbohydrate restriction (Jenkins et al., 1997). Similarly, three days of overfeeding with high carbohydrate intake increased leptin by $28 \%$ and 24-hour energy expenditure by $7 \%$, whereas a similar magnitude of overfeeding on a high fat diet did not (Dirlewanger et al., 2000). However, this may not be practical for physique athletes, as the $40 \%$ energy surplus required to elicit the response may cause substantial fat accretion that would be only minimally offset by the $7 \%$ increase in energy expenditure. This incomplete compensation for high energy intake has also been observed directly in physique athletes (Trexler et al., 2017); resting energy expenditure (REE) acutely increased in the period immediately following competition, but the increase was small compared to the substantial increase in caloric intake. While these results suggest that implementing periods of neutral or positive energy expenditure may help mitigate unfavorable changes in hormone concentrations and energy expenditure during weight loss, such strategies must implement a conservative magnitude and duration of refeeding that does not oppose the overall progression of fat loss. It is also currently unknown how short of a period of maintenance calories would be needed to affect the metabolic rate.

A recent study (Byrne et al., 2018) investigated the effects of two-week diet breaks on weight loss and energy expenditure. One group followed a continuous weight loss program for 16 weeks, whereas the other group alternated between two weeks of an energy deficit and two weeks of energy balance. Both groups spent equal total weeks in an energy deficit of the same size. Results indicated that the group implementing intermittent diet breaks lost more fat mass and total weight and experienced a smaller reduction in REE after correcting for body composition. Overall, the strategy of implementing two-week periods of energy balance partially attenuated the anticipated drop in the metabolic rate, without requiring periods of positive energy balance. However, the overall weight loss process took approximately twice as long, which may be viewed as a prohibitively inconvenient trade-off by some 
competitors.

In an effort to minimize the inefficiency of nonlinear approaches, other studies have implemented diet breaks of shorter duration. In one instance, an 8-week study (Keogh et al., 2014) evaluated one-week diet breaks implemented every other week. The continuous energy restriction group followed a 5500-kilojoule energy restriction each week of the study, whereas the intermittent group alternated between one week of 5500-kilojoule energy restriction and one week of their usual diet. Weight loss observed in the group with diet breaks was not significantly different than the comparator group on a continuous weight loss diet, despite the differing magnitude of energy restriction. A different study (Davoodi et al., 2014) implemented a protocol in which energy was restricted for 11 days, followed by a 3-day diet break. This two-week cycle was repeated three times, for six total weeks. The comparator group, in contrast, implemented continuous energy restriction for the entire six-week period. Results showed that intermittent energy restriction with 3day diet breaks allowed for a similar degree of weight and fat loss, and attenuated reductions in the resting metabolic rate, despite higher average caloric intake throughout the intervention.

The limited data available suggest implementation of nonlinear or intermittent energy restriction strategies, such as diet breaks and refeeds, may partially attenuate some of the unfavorable physiological adaptations to energy restriction, thereby imparting favorable effects on weight loss outcomes. However, these strategies extend the timeline of the weight reduction process. As such, the ideal magnitude, duration, and timing of short-term caloric increases are not currently known. Theoretically, the most efficient strategy would effectively increase caloric intake in a sufficient magnitude and duration to offset physiological adaptations to weight loss, while minimizing the risk of fat accretion and the amount of overall time spent dieting. For a more extensive discussion of nonlinear weight loss strategies, readers are directed to the recent review by Peos and colleagues (2019).

\section{Peak Week}

The final week prior to competition is commonly referred to as "peak week". The overall goal of the peak week is to make muscles appear larger and more detailed by filling glycogen stores while minimizing subcutaneous water. A recent study on peaking practices in bodybuilders found that 94 percent of competitors alter their nutritional approach during the peak week (Chappell and Simper, 2018). Historically, this included approaches such as potassium loading, sodium restriction and water restriction (Kleiner et al., 1990; Shephard, 1994; Steen, 1991), while more recent studies have observed a decline in practices such as sodium and water restriction, these approaches are still used by a significant number of competitors (Chappell and Simper, 2018). However, some or all of these approaches may be misguided in natural competitors, as there are at least theoretical roles for sodium, water and carbohydrate to enhance onstage appearance.

\section{Carbohydrates}

One of the primary goals during the peak week is to enhance muscular fullness. Each gram of glycogen can result in a minimum of 3-4 grams of stored water within muscle in a dehydrated state and up to 17 grams when carbohydrate loading is coupled with adequate hydration (Fernandez-Elias et al., 2015; Olsson and Saltin, 1970). Practically, increasing carbohydrate consumption leading up to a competition should enhance the appearance of a physique. For example, one study observed an increase in bicep muscle thickness the day of the competition when competitors were loading carbohydrates (Bamman et al., 1993). Competitors likely do not gain muscle mass late in contest preparation (Kistler et al., 2014; Rossow et al., 2013); therefore, it is assumed this increase in muscle thickness was due to carbohydrate loading.

A recent study of competitors found $83 \%$ did some form of carbohydrate loading during the final week prior to competition (Chappell and Simper, 2018). In practice, the pattern in which carbohydrates are loaded differs between competitors. Some competitors front load (place their highest carbohydrate days early in the week) while others back load (place their highest carbohydrate days later in the week) (Figure 2). Moreover, there is evidence that after 3 days of glycogen depletion, a large carbohydrate load can cause glycogen supercompensation where as much as 1.79 times initial glycogen can be stored in muscle (Goforth et al., 1997). This may result in an even more full and extreme look onstage; therefore, this approach could be used by competitors in divisions that require a more 
extreme look such as bodybuilding. However, competitors in all divisions may benefit from some form of carbohydrate loading unless they are not lean enough, then they may want to either pick a later competition or continue to lose body fat throughout the final week rather than increasing carbohydrates.

Water

Body water is stored in compartments. Approximately $2 / 3$ of body water is intracellular whereas $1 / 3$ is extracellular. Of the extracellular compartment, $20 \%$ is plasma and the other $80 \%$ is interstitial fluid. A common goal for physique athletes in the peak week is to minimize interstitial fluid. Oftentimes this is done through reducing water intake (Kleiner et al., 1990; Shephard et al., 1994; Steen et al., 1991); however, this can reduce muscle water content, resulting in a decrease in muscle size (Costill et al., 1976). Decreasing water intake also reduces blood volume and blood pressure which can make it more difficult for a competitor to increase blood flow to the desired muscles prior to stepping onstage (during the "pumping up" process), which could result in suboptimal appearance to judges. Anecdotally, some competitors think water is the cause of visual smoothing on show-day, yet in practice it is our collective anecdotal opinion that smoothness is typically the result of excess body fat or loading too many carbohydrates either in total, or too quickly. A $70 \mathrm{~kg}$ male can store approximately $500 \mathrm{~g}$ glycogen (roughly $100 \mathrm{~g}$ in liver and $400 \mathrm{~g}$ in muscle) (Wasserman, 2009). During the transitional period while carbohydrates are being metabolized, and once glycogen stores are full, glucose can accumulate outside of the cell pulling water into the extracellular space. Therefore, it is important that competitors load an appropriate number of carbohydrates over an appropriate timeframe to fill muscle glycogen stores while also consuming ample water.

Sodium

Sodium is the primary extracellular solute. Since water follows solutes, some competitors eliminate sodium in an attempt to reduce extracellular water (Chappell and Simper, 2018). However, plasma sodium is tightly regulated in the kidneys. For example, sodium excretion is significantly reduced when switching to an extremely low sodium diet (Rogacz et al., 1990). Therefore, removing sodium from the diet will not have a significant impact on extracellular fluid removal. Sodium elimination may negatively impact a competitor's look onstage since glucose is transported through a sodium-coupled transporter (Schultz and Curran, 1970), which could influence glycogen storage. Sodium also impacts blood pressure which may affect a competitor's ability to get a pump and subsequently affect transient muscle size and vascularity onstage (Stachenfeld, 2008). Due to sodium's effects on blood pressure it may be advisable to increase sodium on the day of competition, prior to stepping onstage to increase muscle pump and vascularity in appropriate divisions.

\section{Practical Recommendations}

Direct scientific research comparing peaking approaches in physique athletes is lacking. Therefore, we are hesitant to give recommendations on peaking strategies. Based on the current evidence, there is potential harm in reducing sodium, water, or carbohydrates, and almost all competitors manipulate these variables in the peak week. We therefore recommend not reducing any of these three nutritional variables. Carbohydrate loading can be a viable option if the athlete is lean enough, but no comparisons between front- or back-loading exist to determine which is superior and in practice, this may differ between individuals. Ultimately, we recommend testing peak week strategies, if an athlete has sufficient time, before their competition. 


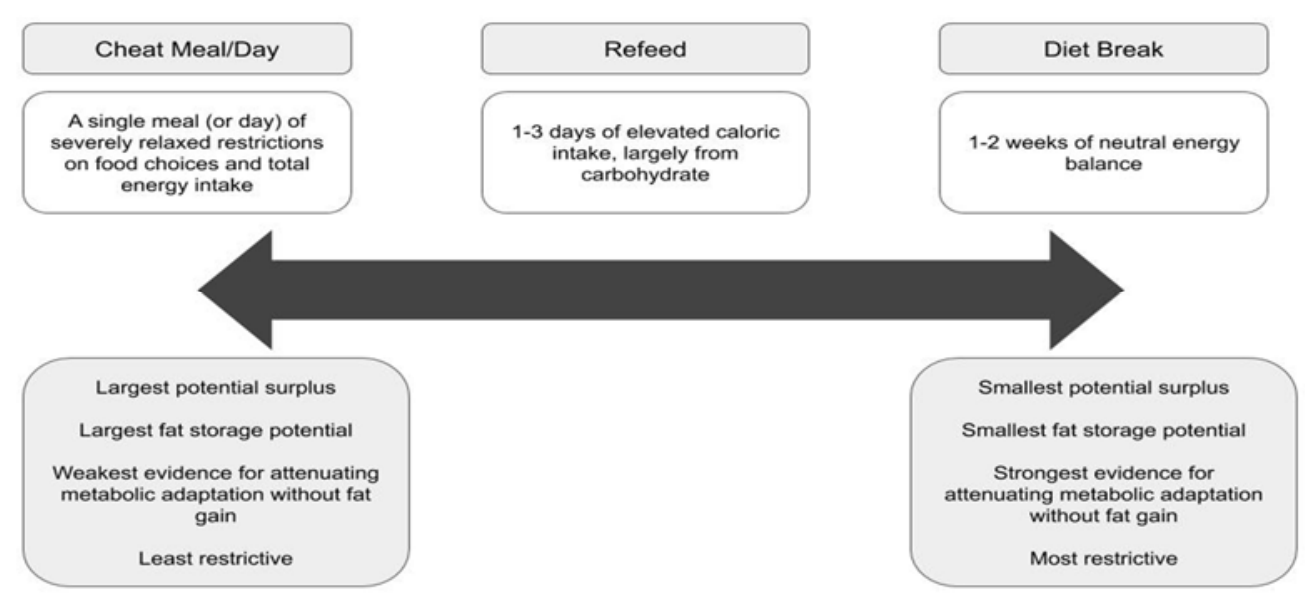

\section{Figure 1}

The spectrum of nonlinear fat loss strategies. Physique athletes often implement nonlinear dieting approaches, in which energy intake is transiently increased during a fat loss phase. Such approaches range from cheat days to strict diet breaks, with each approach featuring unique benefits and drawbacks.

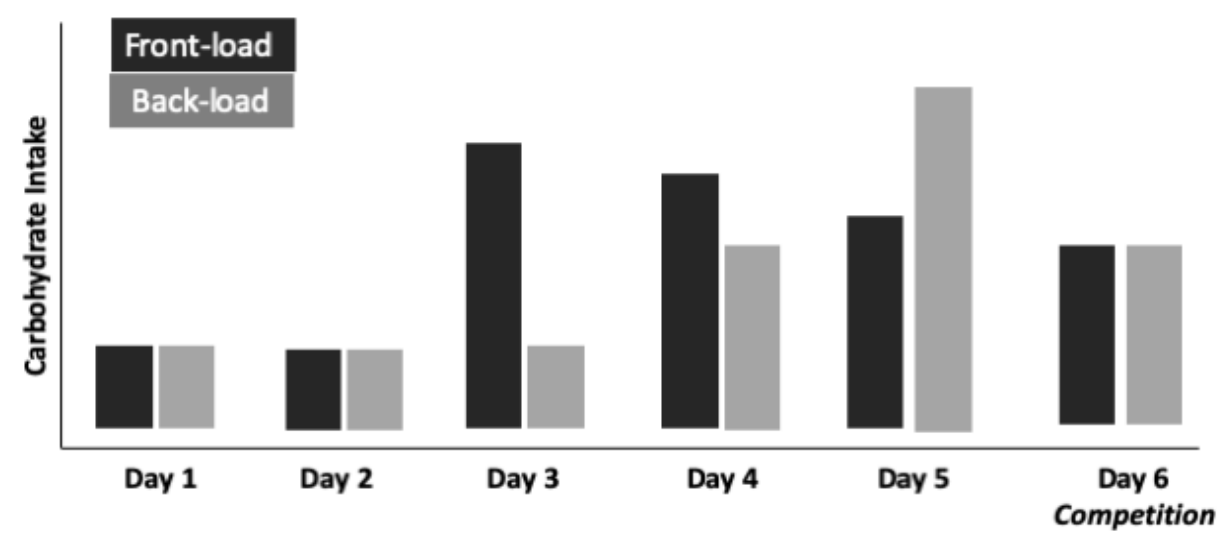

Figure 2

Methods for carbohydrate loading during peak week. Conceptual methods of loading carbohydrates during peak week. Front-loading would begin earlier in the week, resulting in a need to maintain fullness over the course of several days. Back-loading would occur later in the week and could result in less time to make adjustments to a physique. Competition day intake is subjective to how an athlete responds to the prior higher carbohydrate days. 
Table 1

Hypothetical seasonal guidelines for mitigating harm in physique sport

\begin{tabular}{|c|c|}
\hline $\begin{array}{l}\text { Competition } \\
\text { Preparation }\end{array}$ & $\begin{array}{l}\text { 1. Non-dichotomous "good or bad" or "on or off" view of } \\
\text { foods or diet. } \\
\text { 2. Moderate weight loss rates. } \\
\text { 3. Macronutrient or calorie ranges versus food source } \\
\text { restriction. } \\
\text { 4. Flexible meal schedules. } \\
\text { 5. Scheduled, supervised physique assessment, body weight } \\
\text { averages. } \\
\text { 6. Intermittent dieting strategies; semi-regular diet break } \\
\text { weeks or days. }\end{array}$ \\
\hline & 1. Quan \\
\hline Transition to & 2. Return to offseason body composition in $\sim 1-2$ months. \\
\hline Offseason & $\begin{array}{l}\text { 3. Intentional re-introduction of and focus on internal cues; } \\
\text { e.g. hunger. }\end{array}$ \\
\hline Offseason & $\begin{array}{l}\text { 1. Adoption of primarily internal-cue guided energy intake. } \\
\text { 2. Maintain sport-supportive nutrition habits versus relying } \\
\text { on tracking. } \\
\text { 3. Biofeedback (e.g. rate of weight gain) to augment energy } \\
\text { intake. } \\
\text { 4. Qualitative response to biofeedback, e.g., "be less full } \\
\text { after meals". }\end{array}$ \\
\hline
\end{tabular}

*To clarify "Transition to Offseason" point two; as stated in paragraph four of Post-Competition Recovery, we recommend athletes reach sustainable body weight 1-2 months following competition, not necessarily peak-offseason body weight or fat.

\section{Post-Competition Recovery}

While the physiological adaptations associated with contest preparation can be quite unfavorable, they are transient. Reversing adaptations involves both correcting the shortterm energy gap by transitioning from negative to positive energy balance, and restoring fat mass and fat-free mass lost during contest preparation. As for short-term energy balance, it is common for physique athletes to acutely, but abruptly increase caloric intake immediately following competition (Mitchell et al., 2017a; Trexler et al., 2017). Merely transitioning from negative to positive energy balance is likely to have favorable effects on partial restoration of the metabolic rate (Trexler et al., 2017) and hormones that are sensitive to short-term fluctuations in energy availability, such as leptin, ghrelin, and insulin (Borer et al., 2009). However, full recovery of hormones and full reversal of adaptive energy expenditure suppression are likely to require some degree of fat mass and fatfree mass restoration.

At the end of a contest preparation diet, the physique athlete is physiologically primed for weight regain. As reviewed by MacLean and colleagues (2011), such a physiological state is characterized by reduced energy expenditure and elevated hunger. Due to the cyclical nature of 
weight gain and weight reduction associated with bodybuilding (Mitchell et al., 2017a), competitors rarely attempt to maintain contest-level body fat percentages for an extended period of time. Significant weight regain is typically observed within days of competition (Trexler et al., 2017), and binge eating episodes are common within this time period (Andersen et al., 1995). As such, studies have documented cases in which both male and female participants have regained up to $8 \mathrm{~kg}$ in the first 3-4 weeks following competition (Lamar-Hildebrand et al., 1989; Mitchell et al., 2017a). However, there are potential drawbacks to approaches that favor rapid weight regain. Rodent data suggest that overfeeding after sustained weight loss is accompanied by suppressed oxidation of dietary fat and adipocyte hyperplasia (Jackman et al., 2008). As noted in a review by Peos and colleagues (2019), the addition of new adipocytes results in a greater total capacity for fat storage, and yields smaller adipocytes that secrete less leptin and are more prone to energy storage. This propensity for adipocyte hyperplasia may therefore increase the likelihood of regaining more weight than was lost, which is known as body fat overshooting (Saarni et al., 2006). In line with this hypothesis, there is evidence to suggest that athletes with repeated cycles of weight loss and regain tend to have a higher body mass index later in life (Saarni et al., 2006), and it is quite common for humans to overshoot (Saarni et al., 2006). Furthermore, research in the general population suggests that the early phase of weight regain is characterized by preferential gain of fat mass (Saarni et al., 2006), and research in competitive physique athletes has documented similar results (Trexler et al., 2017).

The time course of weight restoration varies significantly in the literature. In some cases, physique athletes return to their baseline weight within nine weeks post-competition (Tinsley et al., 2019), whereas others remain slightly below their baseline weight a full six months after competition (Rossow et al., 2013). Provided competitors maintain positive energy balance after competition and restore a large portion of the body mass lost, blood levels of ghrelin, thyroid hormones (T3 and T4), insulin, and cortisol generally approach baseline levels within 3-4 months following competition (Hulmi et al., 2016; Pardue et al., 2017; Rossow et al., 2013). In the case of leptin (a body fat signal) (Rossow et al., 2013) and testosterone (Pardue et al., 2017; Rossow et al., 2013), levels may not fully recover until 5-6 months postcompetition, but are generally trending to precompetition levels within this timeframe. When it comes to restoration of the menstrual cycle in female competitors that develop amenorrhea, an even longer recovery timeline may be required. The development of menstrual cycle irregularity (or complete cessation) is quite common in female competitors (Hulmi et al., 2016), particularly in competitive classes that require a greater degree of leanness. Unfortunately, efforts to reverse menstrual cycle irregularities often result in prolonged and highly variable recovery timelines.

It seems prudent to advocate that physique athletes implement a rate of weight regain after competition that facilitates full recovery, but avoids deposition of excessive fat mass in the early phase of weight regain. Within the first 1-2 months following competition, the athlete should aim to reach a sustainable and comfortable body weight; after this immediate phase of controlled weight restoration, they would then aim to restore their body fat percentage to their ideal off-season level and fully restore fat-free mass in a fairly linear manner over the subsequent 1-2 months, depending on the magnitude of weight that was lost. In this context, ideal off-season body composition refers to a sustainable body fat percentage that is conducive to normal endocrine status, facilitates lean mass accretion, mitigates the need for excessive weight loss for subsequent competitions, and resolves the hyperphagia experienced following competition. For individuals prone to excessively rapid weight regain, strategies to successfully manage controlled refeeding are likely similar to the strategies that facilitate successful weight loss maintenance. Such strategies include favoring high protein and high fiber intake, regular selfmonitoring of body weight and caloric intake, reducing time spent in sedentary activities, maintaining a similar diet structure with low energy-density foods while avoiding highly palatable foods that could trigger overeating, and maintaining high levels of structured exercise; in essence, such competitors' post-competition recovery diets would be qualitatively similar to their competition diets in composition and schedule, but higher in total calories and 
macronutrients (Melby et al., 2017).

Ultimately, complete recovery of physiological parameters is typically observed 4-6 months following competition, provided the physique athlete maintains positive energy balance and regains a significant portion of the weight lost during the preparation period. It seems likely the timeline of recovery would be accelerated by consumption of a larger energy surplus and a more rapid weight regain.

\section{Physiological Adaptations}

There are several physiological adaptations that occur during contest preparation and recovery. In this section we will cover body composition, menstrual cycle, daily activity and sleep.

Body Composition

Nearly all studies of male competitors observe a reduction in lean mass, while lean mass loss reported in female competitors is typically lower during contest preparation. For example, some studies of female competitors have observed either little lean mass loss during preparation (Halliday et al., 2016; Hulmi et al., 2016) or even a slight increase (Petrizzo et al., 2017; Rohrig et al., 2017). The reason for this difference between sexes is unknown; however, it may be due to baseline testosterone levels being higher in males, making them more responsive to the large decline in testosterone that typically occurs during contest preparation. Lean mass differences could also be due to the level of conditioning required in bodybuilders versus other physique classes. We cover physiological adaptations more fully in previous sections.

Menstrual Cycle

It was previously thought that reproductive function in women was regulated by body fat levels; however, there is increasing evidence that energy availability is the primary driver of reproductive function (Loucks, 2003). Energy availability is the difference between total energy intake and exercise energy expenditure relative to fat free mass. This difference is the energy available for physiological and metabolic processes like creating hormones and building bone (Fagerberg, 2018).

To prevent menstrual cycle abnormalities, female athletes are encouraged to consume at least $30 \mathrm{kcal} / \mathrm{kg}$ lean mass daily. Energy intake below this amount may result in several hormone-related changes, including disruption of luteinizing hormone pulsatility. This can result in amenorrhea, a reduction in bone density and increased fracture risk (Loucks et al., 2011). Yet, to reach competitive levels of body fat onstage, many female competitors may need to consume fewer than 30 $\mathrm{kcal} / \mathrm{kg}$ lean mass at least at some stage during contest preparation. As a result, menstrual cycle abnormalities are widely reported in female competitors (Elliot et al., 1987; Haff et al., 2001; Hulmi et al., 2016; Kleiner et al., 1994; WalbergRankin et al., 1993), which can persist into the postcompetition period. For example, in a cohort of female competitors, $63 \%$ reported menstrual cycle abnormalities during contest preparation; however, 28\% still reported abnormalities after a post-competition recovery period (mean length 17.5 weeks) (Hulmi et al., 2016). Moreover, a drugfree female figure competitor who reached 23.2 $\mathrm{kcal} / \mathrm{kg}$ fat free mass daily during contest preparation did not have a normal menstrual cycle for 71 weeks following competition despite increasing caloric intake to $>30 \mathrm{kcal} / \mathrm{kg}$ lean mass (Halliday et al., 2016).

Taken together, these findings highlight the importance of taking an offseason between competitions, especially for female competitors. During the offseason, caloric intake should be increased to at least $>30 \mathrm{kcal} / \mathrm{kg}$ lean mass daily. Offseason duration should be long enough so that a female competitor regains their monthly cycle and has a normal cycle most of the offseason.

Daily Activity / Non-Exercise Activity Thermogenesis (NEAT)

Total daily energy expenditure (TDEE) is the sum of the basal metabolic rate, the thermic effect of food, exercise activity thermogenesis and non-exercise activity thermogenesis (NEAT). NEAT encompasses all non-exercise movement such as occupation-related activity, leisure-time activity and involuntary activities like postural control, twitching and fidgeting. Energy expended from NEAT can vary up to 2,000 calories per day between individuals of similar size (Levine, 2007). Moreover, caloric expenditure from fidgeting can range from 100-800 calories daily (Ravussin et al., 1986). Due to this large variability, NEAT can play a significant role in energy balance.

Importantly, NEAT may decline while dieting (Peos et al., 2019). In a cross-sectional study, obese participants who lost an average of 
$23 \%$ of their body weight had an $18 \%$ lower TDEE than individuals who had never dieted. Moreover, $71 \%$ of this difference was due to reductions in NEAT in response to dieting (Weigle et al., 1988). In an interventional study, a 10\% reduction in body weight resulted in an average reduction in NEAT of 262 calories/day, whereas a $20 \%$ reduction in body weight reduced NEAT by 500 calories/day on average in obese subjects. Therefore, the amount of weight lost during a diet may impact the magnitude of NEAT reduction (Leibel et al., 1995). To date, there is not direct research on changes in NEAT in physique athletes. However, it is likely that competitors could experience a significant reduction (Rossow et al., 2013).

From a practical standpoint, tracking daily steps may help counteract reductions in NEAT during contest preparation. In fact, a meta-analysis on pedometer use and activity found individuals who track steps using a pedometer increase their step counts (Bravata et al., 2007). However, we caution against competitors pushing to extremes in daily activity because there is evidence that TDEE may not increase further at high levels of activity due to reductions in involuntary movement (Pontzer et al., 2016).

Sleep

It is recommended adults sleep 7-9 hours per night and achieve a sleep efficiency of $85 \%$ (time asleep in bed) to promote general health (Hirshkowitz et al., 2015; Ohayon et al., 2017). Interestingly, athletes tend to sleep less ( 6.5 $\mathrm{h} /$ night) and their sleep quality is lower (Hausswirth et al., 2014; Leeder et al., 2012). While sleep deprivation has a minimal effect on acute strength performance (Fullagar et al., 2015); it plays a role in decision making and mood, which could directly affect a physique athlete. There is also evidence that lack of sleep could compromise body fat loss or elevate LBM loss (Nedeltcheva et al., 2010). Anecdotally, some physique athletes tend to have sleep issues, but there is only one study measuring sleep in a bodybuilder (Pardue et al., 2017). During a 13-month period including contest preparation and recovery, sleep efficiency was reduced by a maximum of $3.6 \%$. Oddly, sleep duration increased $20 \%$ and sleep efficiency increased $8.9 \%$ in the contest preparation phase, likely because the subject started the study sleeping only $\sim 6$ hours per night (Pardue et al., 2017). There was also a trend for subjective sleep quality to decrease in month 4 of contest preparation. Overall, more data are needed with subjective and objective indices before definitive statements regarding the effect of contest preparation on sleep quality or quantity can be made.

Our recommendation for physique athletes is similar to that of other athletes: sleep in a dark environment with a comfortable temperature (use earplugs or eye masks if necessary), restrict mental, emotionally or physically demanding activities prior to bed, and use dim light for $\sim 2$ hours before bedtime (Bonnar et al., 2018). Physique athletes should aim for 8-9 hours of sleep per night. There also appears to be large inter-individual response to the effects of reduced sleep, therefore larger studies are needed, especially in physique athletes (McNeil and StOnge, 2017).

\section{Psychosocial Aspects of Competitive Physique Sport}

Because physique competitors are judged based on aesthetics rather than performance and the necessity of lowering body fat to essential levels, the risks of psychosocial distress (Andersen et al., 1995), and developing eating and body image disorders (Mitchell et al., 2017c) requires consideration. Given the cross-sectional nature of most research in this area, and the multifaceted relationship between numerous factors with eating behavior, the underlying causes of distress are not fully understood. Psychological distress is likely driven by three factors: 1) physiological adaptations to extreme dieting having biopsychosocial effects (Kalm and Semba, 2005), 2) a disproportionate number of individuals with a history of (or risk of developing) psychopathology participating in competition (Mitchell et al., 2017b), and 3) monitoring behaviors secondary to achieving successful body composition changes such as regular self-weighing (Pacanowski et al., 2015), nutrition tracking (Levinson et al., 2017), and physique checking (Shafran et al., 2004). Each factor may contribute to higher incidences of distress and body and eating disorders than is observed in other weight training populations (Goldfield, 2009; Goldfield et al., 2006; Mangweth et al., 2001; Mitchell et al., 2017b; Walberg and Johnston, 1991). Thus, each factor is reviewed, and tentative best-practice guidelines are provided when possible. 
Psychological Distress Among Physique Athletes

While some psychological benefits such as the perceived ability to take on new challenges (Asridis et al., 2014) occur during contest preparation, negative effects manifest as well. In one male natural bodybuilding case study, mood disturbance initially decreased. However, onemonth prior to competition, mood disturbance increased three-fold, then increased seven-fold relative to baseline immediately prior to competition, only returning to normal six months post-season (Rossow et al., 2013). In part, psychological effects of contest preparation are biologically driven. For example, early research found that severe, prolonged, energy restriction increased irritability, introversion, enthusiasm and motivation (Kalm and Semba, 2005).

These effects are partly physiologically mediated; subsequent work exposing healthy men to energy deprivation caused disturbed sleep, fatigue, and urges to consume sweet and savory food (Nindl et al., 1997). Among competitors, compensatory coping behaviors can manifest to control cravings, such as avoidance of social situations (Asridis et al., 2014). Hulmi and colleagues (2016) reported similar physiological signs in female competitors, as a 3 to 4 month postcompetition period was required for most (but not all) hormone markers to return to baseline. In some phases, such as post-competition weight regain, females may experience greater stress as they share parallel physiological responses with men, but may have higher tendencies to dislike their offseason physique possibly mediated by societal pressure (Asridis et al., 2014; Murray et al., 2016).

Indeed, contest preparation drives some psychological effects, but others linger months after competing. Andersen and colleagues (1995) reported $81.5 \%$ of male bodybuilders were preoccupied with food, $46 \%$ engaged in binge eating, and $30-50 \%$ were angrier or more anxious post-competition. Post-competition binge-eating is likely a normal hyperphagic response, whereby an extreme desire for food occurs after substantial weight loss (Dulloo et al., 1997; Weyer et al., 2000), with associated distress likely caused by weight regain conflicting with physique goals.

Non-biological factors also influence disordered eating. Symptoms of depression and negative affect can contribute to binge eating, as suggested by Goldfield and colleagues (2006), who found competitive bodybuilders binge eat more than recreational bodybuilders, despite both reporting similar levels of dietary restraint (Goldfield et al., 2006). This suggests a higher percentage of competitors have attitudes or traits that expose them to greater psychological consequences during contest preparation. Indeed, five of the 16 male physique division competitors in a recent study reported a prior eating or body image disorder (Lenzi et al., 2019), and in a 1991 study $42 \%$ of female competitors used to be anorexic, $67 \%$ were terrified of becoming fat and $50 \%$ experienced uncontrollable urges to eat (Walberg and Johnston, 1991). Some researchers argue binge eating and other behaviors are exacerbated among bodybuilders who judge their self-worth largely on their ability to control their weight and shape (Goldfield, 2009). Since the 1990 's, authors reported higher incidences of disordered eating behaviors, body image concerns, and full eating disorders in competitors of both sexes when compared to non-competitive weightlifters (Goldfield 2009; Goldfield et al., 2006; Mangweth et al., 2001; Mitchell et al., 2017b; Walberg and Johnston, 1991). Recently, Mitchell and colleagues (2017b) reported higher body image concerns in competitors compared to resistance training non-competitors in a metaanalysis, with symptoms associated with general anxiety, social physique anxiety, depression, neuroticism, perfectionism and inversely associated with self-concept and esteem.

Finally, one's dietary restraint disposition can impact psychology. Dietary restraint is subdivided into two types: rigid and flexible control (Westenhoefer et al., 1999). Rigid control is characterized by eating only diet foods, avoiding desired foods, fasting, highly disciplined calorie counting and avoiding "off limit" foods. While flexible control shares the aspect of restraint, it is marked by eating a variety of foods, modifying portions, and adjusting eating if earlier meals contained higher calorie items, and is generally considered more adaptive and sustainable (Westenhoefer et al., 2013). Rigid behaviors like fasting prospectively predict (Agras and Telch, 1998), and in cross-sectional research are linked, with binge eating among women with bulimia and binge eating disorder (Masheb et al., 2011). In weight loss cohorts, there are links between rigid restraint and binge eating, shape/weight 
overvaluation, body dissatisfaction, disinhibited eating, dichotomous thinking, depressive and anxiety symptoms, and poorer wellbeing (Linardon, 2018; Linardon and Mitchell, 2017; Smith et al., 1999; Timko and Perone, 2005; Tylka et al., 2015; Westenhoefer et al., 1999). In contrast, flexible restraint is linked with lowered disordered eating, body image concerns, body weight, and psychological distress (Shearin et al., 1994; Smith et al., 1999; Westenhoefer et al., 1999, 2013) and increases in flexible control are associated with binge eating abstinence, greater weight loss in the course of therapy (Blomquist and Grilo 2011), and in one study, predicted long-term weight maintenance among women with obesity (Teixeira et al., 2010).

While flexible restraint may be more adaptive, adverse outcomes are occasionally associated with it (Linardon and Mitchell, 2017; Timko and Perone, 2005; Tylka et al., 2015). This may stem from overlapping behaviors among categories of restraint, as surprisingly, flexible control is highly correlated with rigid control $\left(r^{\prime} s>\right.$ .50). This calls into question how separate these components are, suggesting promoting flexible control could unintentionally prompt rigid practices (Timko and Perone, 2005; Westenhoefer et al., 2013). Indeed, flexible restraint is associated with positive outcomes only when its shared variance with rigid restraint is removed (Linardon and Mitchell, 2017; Tylka et al., 2015). However, it is unclear how to distinctly prescribe flexible rather than rigid control to avoid potential harm (Tylka et al., 2015). That said, a key factor may be black and white views of eating, which mediate the association between restrained eating and weight regain (Palascha et al., 2015); as viewing foods in non-dichotomous terms is a shared aspect of intuitive eating, which has no restraint component at all (Tylka and Kroon Van Diest, 2013), and flexible control (Westenhoefer et al., 1999).

Physique and dietary monitoring practices likely follow one's restraint disposition, and thus carry potential to increase risks. Some authors speculate self-monitoring in all cases can exacerbate eating disorder symptoms (Simpson and Mazzeo, 2017). Authors of several crosssectional studies report associations between selfmonitoring and binge eating, eating concerns, and shape/weight overvaluation in those with and without clinically significant eating disorders
(Linardon et al., 2019; Linardon and Messer, 2019; Mountford et al., 2006; Shafran et al., 2007; Simpson and Mazzeo 2017). Furthermore, causal links between shape checking and body dissatisfaction exist in some (Shafran et al., 2007), but not all (Bailey and Waller, 2017) experimental work. However, authors of two recent weight loss studies reported no significant differences in eating and body image disorder symptoms between those implementing self-monitoring or those not (Jospe et al., 2018; Steinberg et al., 2014). To explain this discrepancy, it may be these monitoring behaviors are detrimental only when performed rigidly (Fairburn, 2008), or by individuals likely to implement them rigidly, such as those with clinical or subclinical eating disorders.

Mitigating Harm

Given the increased likelihood of competitors already or previously having, or possibly carrying a predisposition towards eating and body image distress, and the obligatory exposure to both the biological drive towards hyperphagia and some of the behaviors which can exacerbate disordered eating, we echo the recommendations of the recently published narrative review specifically on this topic by Helms and colleagues (2019). Table 1 below is reprinted here with permission which outlines recommendations in each "season" of competitive bodybuilding (Helms et al., 2019). To summarize: in the preparation phase, slow to moderate weight loss rates rather than rapid, which are associated with eating and body image disorder symptoms (Mitchell et al., 2017b), should be implemented; non black-and-white views of foods and adherence should be emphasized (Palascha et al., 2015); and rather than high frequency physique checking, scheduled and coach-supervised physique assessment should occur as are performed in clinical eating disorder practice (Fairburn, 2008). In the transition from preparation into the offseason, a tapered but intentional caloric surplus should be implemented

with the goal of steady, but controlled weight regain, and the re-introduction of internal rather than externally-cued nutrition regulation should occur to facilitate a gradual return to nonrestrained eating (e.g. hunger and satiety mediated portion control rather than food weighing and calorie tracking).

Finally, similar to the standard personal 
training practice of screening physical health (Craig and Eickhoff-Shemek, 2015), coaches should enlist the aid of nutrition and mental health care professionals (psychologists, therapists, registered dietitians) to screen the mental health of athletes prior to beginning contest preparation to ensure they are fully informed of risks, and have the appropriate mental health care professionals available to them.

\section{Conclusion}

In conclusion, there are a myriad of factors to consider for physique athletes in contest preparation periods as well as the postcompetition period transitioning into the offseason. Having a structured plan based on the factors within this article is recommended, but additional study of physique athletes is needed to provide more specific guidelines.

\section{References}

Agras WS, Telch CF. The effects of caloric deprivation and negative affect on binge eating in obese bingeeating disordered women. Behav Ther, 1998; 29: 491-503

Alwan N, Moss SL, Elliott-Sale KJ, Davies IG, Enright K. A Narrative Review on Female Physique Athletes: The Physiological and Psychological Implications of Weight Management Practices. Int J Sport Nutr Exerc Metab, 2019; 13: 1-8

Andersen RE, Barlett SJ, Morgan GD, Brownell KD. Weight loss, psychological, and nutritional patterns in competitive male body builders. Int J Eat Disord, 1995; 18: 49-57

Anderson JE. A role for nitric oxide in muscle repair: nitric oxide-mediated activation of muscle satellite cells. Mol Biol Cell, 2000; 11: 1859-74

Antonio J, Ellerbroek A, Peacock C, Silver T. Casein Protein Supplementation in Trained Men and Women: Morning versus Evening. Int J Exerc Sci, 2017; 10: 479-486

Aragon AA, Schoenfeld BJ. Nutrient timing revisited: is there a post-exercise anabolic window? J Int Soc Sports Nutr, 2013; 10: 5

Areta JL, Burke LM, Ross ML, Camera DM, West DW, Broad EM, Jeacocke NA, Moore DM, Stellingwerff T, Phillips SM, Hawley JA, Coffey VG. Timing and distribution of protein ingestion during prolonged recovery from resistance exercise alters myofibrillar protein synthesis. J Physiol, 2013; 591: 2319-31

Asridis A, O'Halloran P, Liamputtong P. Female Bodybuilding: Perceived Social and Psychological Effects of Participating in the Figure Class, Women in Sport and Physical Activity Journal, 2014; 22: 24-29

Atherton PJ, Etheridge T, Watt PW, Wilkinson D, Selby A, Rankin D, Smith K, Rennie MJ. Muscle full effect after oral protein: time-dependent concordance and discordance between human muscle protein synthesis and mTORC1 signaling. Am J Clin Nutr, 2010; 92: 1080-8

Bailey N, Waller G. Body checking in non-clinical women: Experimental evidence of a specific impact on fear of uncontrollable weight gain. Int J Eat Disord, 2017; 50: 693-697

Bailey SJ, Vanhatalo A, Winyard PG, Jones AM. The nitrate-nitrite-nitric oxide pathway: Its role in human exercise physiology. Euro J Sport Sci, 2011; 309-320

Bamman MB, Hunter GR, Newton LE, Roney LE, Khaled MA. Changes in body composition, diet, and strength of bodybuilders during the 12 weeks prior to competition. J Sports Med Phys Fitness, 1993; 33: 383-91

Bandegan A, Courtney-Martin G, Rafii M, Pencharz PB, Lemon PW. Indicator Amino Acid-Derived Estimate of Dietary Protein Requirement for Male Bodybuilders on a Nontraining Day Is Several-Fold Greater than the Current Recommended Dietary Allowance. J Nutr, 2017; 147: 850-857

Bastos-Silva VJ, Prestes J, Geraldes AR. Effect of Carbohydrate Mouth Rinse on Training Load Volume in Resistance Exercises. J Strength Cond Res, 2019; 33: 1653-1657

Bazzucchi I, Patrizio F, Felici F, Nicolo A, Sacchetti M. Carbohydrate Mouth Rinsing: Improved Neuromuscular Performance During Isokinetic Fatiguing Exercise. Int J Sports Physiol Perform, 2017; 12: $1031-1038$ 
Bescos R, Sureda A, Tur JA, Pons A. The effect of nitric-oxide-related supplements on human performance. Sports Med, 2012; 42: 99-117

Bin Naharudin NM, Yusof A, Shaw H, Stockton M, Clayton DJ, James LJ. Breakfast Omission Reduces Subsequent Resistance Exercise Performance. J Strength Cond Res, 2019; 33: 1766-1772

Blomquist KK, Grilo CM. Predictive significance of changes in dietary restraint in obese patients with binge eating disorder during treatment. Int J Eat Disord, 2011; 44: 515-23

Bonnar D, Bartel K, Kakoschke N, Lang C. Sleep Interventions Designed to Improve Athletic Performance and Recovery: A Systematic Review of Current Approaches. Sports Med, 2018; 48: 683-703

Borer KT, Wuorinen E, Ku K, Burant C. Appetite responds to changes in meal content, whereas ghrelin, leptin, and insulin track changes in energy availability. J Clin Endocrinol Metab, 2009; 94: 2290-8

Bravata DM, Smith-Spangler C, Sundaram V, Gienger AL, Lin N, Lewis R, Stave CD, Olkin I, Sirard JR. Using pedometers to increase physical activity and improve health: a systematic review. JAMA, 2007; 298: 2296-304

Burke LM, Slater G, Broad EM, Haukka J, Modulon S, Hopkins WG. Eating patterns and meal frequency of elite Australian athletes. Int J Sport Nutr Exerc Metab, 2003; 13: 521-38

Byrne NM, Sainsbury A, King NA, Hills AP, Wood RE. Intermittent energy restriction improves weight loss efficiency in obese men: the MATADOR study. Int J Obes (Lond), 2018; 42: 129-138

Campbell BI, Aguilar D, Conlin L, Vargas A, Schoenfeld BJ, Corson A, Gai C, Best S, E. Galvan, Couvillion K. Effects of High Versus Low Protein Intake on Body Composition and Maximal Strength in Aspiring Female Physique Athletes Engaging in an 8-Week Resistance Training Program. Int J Sport Nutr Exerc Metab, 2018; 28: 580-585

Carbone JW, Pasiakos SM, Vislocky LM, Anderson JM, Rodriguez NR. Effects of short-term energy deficit on muscle protein breakdown and intramuscular proteolysis in normal-weight young adults. Appl Physiol Nutr Metab, 2014; 39: 960-8

Chappell AJ, Simper T, Barker ME. Nutritional strategies of high level natural bodybuilders during competition preparation, J Int Soc Sports Nutr, 2018; 15: 4

Chappell AJ, Simper T. Nutritional Peak Week and Competition Day Strategies of Competitive Natural Bodybuilders, Sports (Basel), 2018; 6

Clarke ND, Kornilios E, Richardson DL. Carbohydrate and Caffeine Mouth Rinses Do Not Affect Maximum Strength and Muscular Endurance Performance. J Strength Cond Res, 2015; 29: 2926-31

Coggan AR, Leibowitz JL, Kadkhodayan A, Thomas DP, Ramamurthy S, Spearie CA, Waller S, Farmer M, Peterson LR. Effect of acute dietary nitrate intake on maximal knee extensor speed and power in healthy men and women. Nitric Oxide, 2015; 48: 16-21

Coggan AR, Peterson LR. Dietary Nitrate Enhances the Contractile Properties of Human Skeletal Muscle. Exerc Sport Sci Rev, 2018; 46: 254-261

Cooper R, Naclerio F, Allgrove J, Jimenez A. Creatine supplementation with specific view to exercise/sports performance: an update. J Int Soc Sports Nutr, 2012; 9: 33

Costill DL, Cote R, Fink W. Muscle water and electrolytes following varied levels of dehydration in man. J Appl Physiol, 1976; 40: 6-11

Costill DL, Dalsky GP, Fink WJ. Effects of caffeine ingestion on metabolism and exercise performance. Med Sci Sports, 1978; 10: 155-8

Davoodi SH, Ajami M, Ayatollahi SA, Dowlatshahi K, Javedan G, Pazoki-Toroudi HR. Calorie shifting diet versus calorie restriction diet: a comparative clinical trial study. Int J Prev Med, 2014; 5: 447-56

Dean V, Burke L. Clinical Sports Nutrition. McGraw-Hill; 2006

Decimoni LS, Curty VM, Almeida L, Koch AJ, Willardson JM, Machado M. Carbohydrate mouth rinsing improves resistance training session performance. Int J Sports Sci, 2018; 13: 804-809

Dhillon J, Craig BA, Leidy HL, Amankwaah AF, Anguah KO, Jacobs A, Jones BL, Jones JB, Keeler CL, Keller CE, McCrory MA, Rivera RL, Slebodnik M, Mattes RD, Tucker RM. The Effects of Increased Protein Intake on Fullness: A Meta-Analysis and Its Limitations. J Acad Nutr Diet, 2016; 116: 968-83

Dirlewanger M, di Vetta V, Guenat E, Battilana P, Seematter G, Schneiter P, Jequier E, Tappy L. Effects of shortterm carbohydrate or fat overfeeding on energy expenditure and plasma leptin concentrations in healthy female subjects. Int J Obes Relat Metab Disord, 2000; 24: 1413-8 
Dudgeon WD, Kelley EP, Scheett TP. Effect of Whey Protein in Conjunction With a Caloric-Restricted Diet and Resistance Training. J Strength Cond Res, 2017; 31: 1353-1361

Dulloo AG, Jacquet J, Girardier L. Poststarvation hyperphagia and body fat overshooting in humans: a role for feedback signals from lean and fat tissues. Am J Clin Nutr, 1997; 65: 717-23

Dunkin JE, Phillips SM. The Effect of a Carbohydrate Mouth Rinse on Upper-Body Muscular Strength and Endurance. J Strength Cond Res, 2017; 31: 1948-1953

Elliot DL, Goldberg L, Kuehl KS, Catlin DH. Characteristics of Anabolic-Androgenic Steroid-Free Competitive Male and Female Bodybuilders. Phys Sportsmed, 1987; 15: 169-79

Fagerberg P. Negative Consequences of Low Energy Availability in Natural Male Bodybuilding: A Review. Int J Sport Nutr Exerc Metab, 2018; 28: 385-402

Fairburn CG. Cognitive behavior therapy and eating disorders. Guilford Press; 2008

Fernandez-Elias VE, Ortega JF, Nelson RK, Mora-Rodriguez R. Relationship between muscle water and glycogen recovery after prolonged exercise in the heat in humans. Eur J Appl Physiol, 2015; 115: 191926

Fullagar HH, Skorski S, Duffield R, Hammes D, Coutts AJ, Meyer T. Sleep and athletic performance: the effects of sleep loss on exercise performance, and physiological and cognitive responses to exercise. Sports Med, 2015; 45: 161-86

Garthe I, Raastad T, Refsnes PE, Koivisto A, Sundgot-Borgen J. Effect of two different weight-loss rates on body composition and strength and power-related performance in elite athletes. Int J Sport Nutr Exerc Metab, 2011; 21: 97-104

Goforth HW, Arnall DA, Bennett BL, Law PG. Persistence of supercompensated muscle glycogen in trained subjects after carbohydrate loading. J Appl Physiol (1985), 1997; 82: 342-7

Goldfield GS. Body image, disordered eating and anabolic steroid use in female bodybuilders. Eat Disord, 2009; 17: $200-10$

Goldfield GS, Blouin AG, Woodside DB. Body image, binge eating, and bulimia nervosa in male bodybuilders. Can J Psychiatry, 2006; 51: 160-8

Goldstein ER, Ziegenfuss T, Kalman D, Kreider R, Campbell B, Wilborn C, Taylor L, Willoughby D, Stout J, Graves BS, Wildman R, Ivy JL, Spano M, Smith AE, Antonio J. International society of sports nutrition position stand: caffeine and performance. J Int Soc Sports Nutr, 2010; 7: 5

Grgic J, Mikulic P, Schoenfeld BJ, Bishop DJ, Pedisic Z. The Influence of Caffeine Supplementation on Resistance Exercise: A Review. Sports Med, 2019; 49: 17-30

Grgic J, Trexler ET, Lazinica B, Pedisic Z. Effects of caffeine intake on muscle strength and power: a systematic review and meta-analysis. J Int Soc Sports Nutr, 2018; 15: 11

Hackett DA, Johnson NA, Chow CM. Training practices and ergogenic aids used by male bodybuilders. J Strength Cond Res, 2013; 27: 1609-17

Haff GG, Schroeder CA, Koch AJ, Kuphal KE, Comeau MJ, Potteiger JA. The effects of supplemental carbohydrate ingestion on intermittent isokinetic leg exercise. J Sports Med Phys Fitness, 2001; 41: 21622

Halliday TM, Loenneke JP, Davy BM. Dietary Intake, Body Composition, and Menstrual Cycle Changes during Competition Preparation and Recovery in a Drug-Free Figure Competitor: A Case Study. Nutrients, 2016; 8

Harpaz E, Tamir S, Weinstein A, Weinstein Y. The effect of caffeine on energy balance. J Basic Clin Physiol Pharmacol, 2017; 28: 1-10

Harris RC, Tallon MJ, Dunnett J, Boobis L, Coakley J, Kim HJ, Fallowfield JL, Hill CA, Sale C, Wise JA. 2006. The absorption of orally supplied beta-alanine and its effect on muscle carnosine synthesis in human vastus lateralis. Amino Acids, 30: 279-89

Hausswirth C, Louis J, Aubry A, Bonnet G, Duffield R, Meur LE. Evidence of disturbed sleep and increased illness in overreached endurance athletes. Med Sci Sports Exerc, 2014; 46: 1036-45

Hector AJ, Phillips SM. Protein Recommendations for Weight Loss in Elite Athletes: A Focus on Body Composition and Performance. Int J Sport Nutr Exerc Metab, 2018; 28: 170-177

Helms ER, Aragon AA, Fitschen PJ. Evidence-based recommendations for natural bodybuilding contest preparation: nutrition and supplementation. J Int Soc Sports Nutr, 2014; 11: 20 
Helms ER, Prnjak K, Linardon J. Towards a Sustainable Nutrition Paradigm in Physique Sport: A Narrative Review. Sports (Basel), 2019; 7

Helms ER, Zinn CR, Rowlands DS, Naidoo R, Cronin J. High-protein, low-fat, short-term diet results in less stress and fatigue than moderate-protein moderate-fat diet during weight loss in male weightlifters: a pilot study. Int J Sport Nutr Exerc Metab, 2015; 25: 163-70

Heni SM, Kullmann C, Ketterer M, Guthoff M, Bayer H, Staige F, Machicao F, Haring HU, Preissl H, Veit R, Fritsche A. Differential effect of glucose ingestion on the neural processing of food stimuli in lean and overweight adults. Hum Brain Mapp, 2014; 35: 918-28

Hill CA, Harris RC, Kim HJ, Harris BD, Sale C, Boobis LH, Kim CK, Wise JA. Influence of beta-alanine supplementation on skeletal muscle carnosine concentrations and high intensity cycling capacity. Amino Acids, 2007; 32: 225-33

Hirshkowitz M, Whiton K, Albert SM, Alessi C, Bruni O, DonCarlos L, Hazen N, Herman J, Katz ES, Kheirandish-Gozal L, Neubauer DN, O'Donnell AE, Ohayon M, Peever J, Rawding R, Sachdeva RC, Setters B, Vitiello MV, Ware JC, Adams-Hillard PJ. National Sleep Foundation's sleep time duration recommendations: methodology and results summary. Sleep Health, 2015; 1: 40-43

Hobson RM, Saunders B, Ball G, Harris RG, Sale C. Effects of beta-alanine supplementation on exercise performance: a meta-analysis. Amino Acids, 2012; 43: 25-37

Hoffman JR., Ratamess NA, Faigenbaum AD, Ross R, Kang, Stout JR, Wise JA. Short-duration beta-alanine supplementation increases training volume and reduces subjective feelings of fatigue in college football players. Nutr Res, 2008; 28: 31-5

Hoffman J, Ratamess N, Kang J, Mangine G, Faigenbaum A, Stout J. Effect of creatine and beta-alanine supplementation on performance and endocrine responses in strength/power athletes. Int J Sport Nutr Exerc Metab, 2006; 16: 430-46

Holt SH, Miller SH, Petocz P, Farmakalidis E. A satiety index of common foods. Eur J Clin Nutr, 1995; 49: 67590

Hudson JL, Bergia RE, Campbell WW. Effects of protein supplements consumed with meals, versus between meals, on resistance training-induced body composition changes in adults: a systematic review. Nutr Rev, 2018; 76: 461-468

Hulmi JJ, Isola V, Suonpaa M, Jarvinen NJ, Kokkonen M, Wennerstrom A, Nyman K, Perola M, Ahtiainen JP, Hakkinen K. The Effects of Intensive Weight Reduction on Body Composition and Serum Hormones in Female Fitness Competitors. Front Physiol, 2016; 7: 689

Hultman E, Soderlund K, Timmons JA, Cederblad G, Greenhaff PL. Muscle creatine loading in men. J Appl Physiol (1985), 1996; 81: 232-7

Hutchison AT, Heilbronn LK. Metabolic impacts of altering meal frequency and timing - Does when we eat matter? Biochimie, 2016; 124: 187-197

Iraki J, Fitschen P, Espinar S, Helms E. Nutrition Recommendations for Bodybuilders in the Off-Season: A Narrative Review. Sports (Basel), 2019; 7

Ismaeel A, Weems S, Willoughby. A Comparison of the Nutrient Intakes of Macronutrient-Based Dieting and Strict Dieting Bodybuilders. Int J Sport Nutr Exerc Metab, 2018; 28: 502-508

Craig AC, Eickhoff-Shemek. Adherence to ACSM's Pre-Activity Screening Procedures in Fitness Facilities: a National Investigation. Journal of Physical Education and Sports Management, 2015; 2

Jackman MR, Steig A, Higgins JA, Johnson GC, Fleming-Elder BK, Bessesen H, MacLean PS. Weight regain after sustained weight reduction is accompanied by suppressed oxidation of dietary fat and adipocyte hyperplasia. Am J Physiol Regul Integr Comp Physiol, 2008; 294: R1117-29

Jager RC, Kerksick M, Campbell BI, Cribb PJ, Wells SD, Skwiat TM, Purpura M, Ziegenfuss TN, Ferrando AA, Arent SM, Smith-Ryan AE, Stout JR, Arciero PJ, Ormsbee MJ, Taylor LW, Wilborn CD, Kalman DS, Kreider R, Willoughby DS, Hoffman JR, Krzykowski JL, Antonio J. International Society of Sports Nutrition Position Stand: protein and exercise. J Int Soc Sports Nutr, 2017; 14: 20

Jenkins AB, Markovic TP, Fleury A, Campbell LV. Carbohydrate intake and short-term regulation of leptin in humans. Diabetologia, 1997; 40: 348-51

Jentjens R, Jeukendrup A. Determinants of post-exercise glycogen synthesis during short-term recovery. Sports Med, 2003; 33: 117-44 
Jospe MR, Brown RC, Williams SM, Roy M, Meredith-Jones KA, Taylor RW. Self-monitoring has no adverse effect on disordered eating in adults seeking treatment for obesity. Obes Sci Pract, 2018; 4: 283-288

Joy JM, Vogel RM, Broughton KS, Kudla U, Kerr NY, Davison JM, Wildman RC, DiMarco NM. Daytime and nighttime casein supplements similarly increase muscle size and strength in response to resistance training earlier in the day: a preliminary investigation. J Int Soc Sports Nutr, 2018; 15: 24

Kahleova H, Lloren J, Mashchak A, Hill M, Fraser GA. Meal Frequency and Timing Are Associated with Changes in Body Mass Index in Adventist Health Study 2. J Nutr, 2017; 147: 1722-1728

Kalm LM, Semba RD. They starved so that others be better fed: remembering Ancel Keys and the Minnesota experiment. J Nutr, 2005; 135: 1347-52

Keim NL, Stern JS, Havel PJ. Relation between circulating leptin concentrations and appetite during a prolonged, moderate energy deficit in women. Am J Clin Nutr, 1998; 68: 794-801

Kelm M. Nitric oxide metabolism and breakdown. Biochim Biophys Acta, 1999; 1411: 273-89

Keogh JB, Pedersen E, Petersen KS, Clifton PM. Effects of intermittent compared to continuous energy restriction on short-term weight loss and long-term weight loss maintenance. Clin Obes, 2014; 4: 150-6

Kerksick CM, Wilborn CD, Roberts MD, Smith-Ryan A, Kleiner S, Jager R, Collins R, Cooke M, Davis JN, Galvan E, Greenwood M, Lowery LM, Wildman R, Antonio J, Kreider RB. ISSN exercise \& sports nutrition review update: research \& recommendations. J Int Soc Sports Nutr, 2018; 15: 38

Kim IY, Schutzler S, Schrader A, Spencer HJ, Azhar G, Ferrando AA, Wolfe RR. The anabolic response to a meal containing different amounts of protein is not limited by the maximal stimulation of protein synthesis in healthy young adults. Am J Physiol Endocrinol Metab, 2016; 310: E73-80

Kistler BM, Fitschen PJ, Ranadive SM, Fernhall B, Wilund KR. Case study: Natural bodybuilding contest preparation. Int J Sport Nutr Exerc Metab, 2014; 24: 694-700

Kleiner SM, Bazzarre TL, Ainsworth BE. Nutritional status of nationally ranked elite bodybuilders. Int J Sport Nutr, 1994; 4: 54-69

Kleiner SM, Bazzarre TL, Litchford MD. Metabolic profiles, diet, and health practices of championship male and female bodybuilders. J Am Diet Assoc, 1990; 90: 962-7

Kouw IW, Holwerda AM, Trommelen J, Kramer IF, Bastiaanse J, Halson SL, Wodzig WK, Verdijk LB, van Loon LJ. Protein Ingestion before Sleep Increases Overnight Muscle Protein Synthesis Rates in Healthy Older Men: A Randomized Controlled Trial. J Nutr, 2017; 147: 2252-2261

Kreider RB, Kalman DS, Antonio J, Ziegenfuss TN, Wildman R, Collins R, Candow DG, Kleiner SM, Almada AL, Lopez HL. International Society of Sports Nutrition position stand: safety and efficacy of creatine supplementation in exercise, sport, and medicine. J Int Soc Sports Nutr, 2017; 14: 18

Lamar-Hildebrand N, Saldanha L, Endres J.Dietary and exercise practices of college-aged female bodybuilders. J Am Diet Assoc, 1989; 89: 1308-10

Lambert CP, Frank LL, Evans WJ. Macronutrient considerations for the sport of bodybuilding. Sports Med, 2004; 34: 317-27

Leeder J, Glaister M, Pizzoferro K, Dawson J, Pedlar C. Sleep duration and quality in elite athletes measured using wristwatch actigraphy. J Sports Sci, 2012; 30: 541-5

Leibel RL, Rosenbaum M, Hirsch J. Changes in energy expenditure resulting from altered body weight. $N$ Engl J Med, 1995; 332: 621-8

Leiter JR, Upadhaya R, Anderson JE. Nitric oxide and voluntary exercise together promote quadriceps hypertrophy and increase vascular density in female 18-mo-old mice. Am J Physiol Cell Physiol, 2012; 302: C1306-15

Lenzi JL, Teixeira EL, de Jesus G, Schoenfeld BJ, de Salles Painelli V. Dietary Strategies of Modern Bodybuilders During Different Phases of the Competitive Cycle. J Strength Cond Res, 2019

Levine JA. Nonexercise activity thermogenesis--liberating the life-force. J Intern Med, 2007; 262: 273-87

Levinson CA, Fewell L, Brosof LC. My Fitness Pal calorie tracker usage in the eating disorders. Eat Behav, 2017; 27: $14-16$

Linardon J. The relationship between dietary restraint and binge eating: Examining eating-related self-efficacy as a moderator. Appetite, 2018; 127: 126-129 
Linardon J, Fuller-Tyszkiewicz M, de la Piedad Garcia X, Messer M, Brennan L. Do body checking and avoidance behaviours explain variance in disordered eating beyond attitudinal measures of body image? Eat Behav, 2019; 32: 7-11

Linardon J, Messer M. My fitness pal usage in men: Associations with eating disorder symptoms and psychosocial impairment. Eat Behav, 2019; 33: 13-17

Linardon J, Mitchell S. Rigid dietary control, flexible dietary control, and intuitive eating: Evidence for their differential relationship to disordered eating and body image concerns. Eat Behav, 2017; 26: 16-22

Longland TM, Oikawa SY, Mitchell CJ, Devries MJ, Phillips SM. Higher compared with lower dietary protein during an energy deficit combined with intense exercise promotes greater lean mass gain and fat mass loss: a randomized trial. Am J Clin Nutr, 2016; 103: 738-46

Loucks AB. Energy availability, not body fatness, regulates reproductive function in women. Exerc Sport Sci Rev, 2003; 31: 144-8

Loucks AB, Kiens B, Wright H. Energy availability in athletes. J Sports Sci, 2011; 29 Suppl 1: S7-15

MacDougall JD, Ray S, Sale DG, McCartney N, Lee P, Garner P. Muscle substrate utilization and lactate production. Can J Appl Physiol, 1999; 24: 209-15

Maclean PS, Bergouignan A, Cornier MA, Jackman MR. Biology's response to dieting: the impetus for weight regain. Am J Physiol Regul Integr Comp Physiol, 2011; 301: R581-600

Macnaughton LS, Wardle SL, Witard OC, McGlory C, Hamilton DL, Jeromson S, Lawrence SE, Wallis GA, Tipton KD. The response of muscle protein synthesis following whole-body resistance exercise is greater following $40 \mathrm{~g}$ than $20 \mathrm{~g}$ of ingested whey protein. Physiol Rep, 2016; 4

Maestu J, Eliakim A, Jurimae J, Valter I, Jurimae T. Anabolic and catabolic hormones and energy balance of the male bodybuilders during the preparation for the competition. J Strength Cond Res, 2010; 24: 107481

Mangweth B, Pope HG, Kemmler G, Ebenbichler C, Hausmann A, De Col C, Kreutner B, Kinzl J, Biebl W. Body image and psychopathology in male bodybuilders. Psychother Psychosom, 2001; 70: 38-43

Masheb RM, Grilo CM, White MA. An examination of eating patterns in community women with bulimia nervosa and binge eating disorder. Int J Eat Disord, 2011; 44: 618-24

Maughan RJ, Burke RM, Dvorak J, Larson-Meyer DE, Peeling P, Phillips SM, Rawson ES, Walsh NP, Garthe I, Geyer H, Meeusen R, van Loon LJ, Shirreffs SM, Spriet M, Stuart A, Vernec K. Currell V. Ali M, Budgett RG, Ljungqvist A, Mountjoy M, Pitsiladis YP, Soligard T, Erdener U, Engebretsen L. IOC consensus statement: dietary supplements and the high-performance athlete. Br J Sports Med, 2018; 52 : $439-455$

McMahon NF, Leveritt MD, Pavey TG. The Effect of Dietary Nitrate Supplementation on Endurance Exercise Performance in Healthy Adults: A Systematic Review and Meta-Analysis. Sports Med, 2017; 47: 735756

McNeil J, St-Onge MP. Increased energy intake following sleep restriction in men and women: A one-size-fitsall conclusion? Obesity (Silver Spring), 2017; 25: 989-992

Melby CL, Paris HL, Foright HL, Peth J. Attenuating the Biologic Drive for Weight Regain Following Weight Loss: Must What Goes Down Always Go Back Up? Nutrients, 2017; 9

Mero AA, Huovinen H, Matintupa O, Hulmi JJ, Puurtinen R, Hohtari H, Karila TA. Moderate energy restriction with high protein diet results in healthier outcome in women. J Int Soc Sports Nutr, 2010; 7: 4

Mitchell JB, DiLauro PC, Pizza FX, Cavender DL. The effect of preexercise carbohydrate status on resistance exercise performance. Int J Sport Nutr, 1997; 7: 185-96

Mitchell L, Hackett D, Gifford J, Estermann F, O'Connor H. Do Bodybuilders Use Evidence-Based Nutrition Strategies to Manipulate Physique? Sports (Basel), 2017a; 5

Mitchell L, Murray SB, Cobley S, Hackett D, Gifford J, Capling L, O'Connor H. Muscle Dysmorphia Symptomatology and Associated Psychological Features in Bodybuilders and Non-Bodybuilder Resistance Trainers: A Systematic Review and Meta-Analysis. Sports Med, 2017b; 47: 233-259

Mitchell L, Murray SB, Hoon M, Hackett D, Prvan T, O'Connor H. Correlates of muscle dysmorphia symptomatology in natural bodybuilders: Distinguishing factors in the pursuit of hyper-muscularity. Body Image, 2017c; 22: 1-5 
Mitchell L, Slater G, Hackett D, Johnson N, O'Connor H. Physiological implications of preparing for a natural male bodybuilding competition. Eur J Sport Sci, 2018; 18: 619-629

Moore DR, Robinson MJ, Fry JL, Tang JE, Glover EI, Wilkinson SB, Prior T, Tarnopolsky MA, Phillips SM. Ingested protein dose response of muscle and albumin protein synthesis after resistance exercise in young men. Am J Clin Nutr, 2009; 89: 161-8

Morton RW, Murphy KT, McKellar SR, Schoenfeld BJ, Henselmans M, Helms E, Aragon AA, Devries MC, Banfield L, Krieger JW, Phillips SM. A systematic review, meta-analysis and meta-regression of the effect of protein supplementation on resistance training-induced gains in muscle mass and strength in healthy adults. Br J Sports Med, 2018; 52: 376-384

Mosher SL, Sparks SA, Williams EL, Bentley DJ, McNaughton LR. Ingestion of a Nitric Oxide Enhancing Supplement Improves Resistance Exercise Performance. J Strength Cond Res, 2016; 30: 3520-3524

Mountford V, Haase A, Waller G. Body checking in the eating disorders: Associations between cognitions and behaviors. Int J Eat Disord, 2006; 39: 708-15

Murray M, Maras D, Goldfield GS. Excessive Time on Social Networking Sites and Disordered Eating Behaviors Among Undergraduate Students: Appearance and Weight Esteem as Mediating Pathways. Cyberpsychol Behav Soc Netw, 2016; 19: 709-715

Nawrot PS. Jordan J, Eastwood J, Rotstein A, Hugenholtz A, Feeley M. Effects of caffeine on human health. Food Addit Contam, 2003; 20: 1-30

Nedeltcheva AV, Kilkus JM, Imperial J, Schoeller DA, Penev PD. Insufficient sleep undermines dietary efforts to reduce adiposity. Ann Intern Med, 2010; 153: 435-41

Nindl BC, Friedl NC, Frykman PC, Marchitelli LJ, Shippee RL, Patton JF. Physical performance and metabolic recovery among lean, healthy men following a prolonged energy deficit. Int J Sports Med, 1997; 18: $317-24$

Ohayon M, Wickwire EM, Hirshkowitz M, Albert SM, Avidan A, Daly FJ, Dauvilliers Y, Ferri R, Fung C, Gozal D, Hazen G, Krystal A, Lichstein K, Mallampalli M, Plazzi G, Rawding R, Scheer FA, Somers V, Vitiello MV. National Sleep Foundation's sleep quality recommendations: first report. Sleep Health, 2017; 3: 6-19

Olsson KE, Saltin B. Variation in total body water with muscle glycogen changes in man. Acta Physiol Scand, 1970; 80: 11-8

Ortenblad N, Westerblad H, Nielsen J. Muscle glycogen stores and fatigue. J Physiol, 2013; 591: 4405-13

Ostojic SM, Ahmetovic Z. Gastrointestinal distress after creatine supplementation in athletes: are side effects dose dependent? Res Sports Med, 2008; 16: 15-22

Outlaw JJ, Smith-Ryan AE, Buckley AL, Urbina SL, Hayward S, Wingfield HL, Campbell B, Foster C, Taylor LW, Wilborn CD. Effects of beta-Alanine on Body Composition and Performance Measures in Collegiate Women. J Strength Cond Res, 2016; 30: 2627-37

Pacanowski CR, Linde JA, Neumark-Sztainer D. Self-Weighing: Helpful or Harmful for Psychological WellBeing? A Review of the Literature. Curr Obes Rep, 2015; 4: 65-72

Painelli VS, Roschel H, Gualano B, Del-Favero S, Benatti FB, Ugrinowitsch C, Tricoli V, Lancha AH. The effect of carbohydrate mouth rinse on maximal strength and strength endurance. Eur J Appl Physiol, 2011; 111: 2381-6

Palascha A, van Kleef AE, van Trijp HC. How does thinking in Black and White terms relate to eating behavior and weight regain? J Health Psychol, 2015; 20: 638-48

Pardue A, Trexler ET, Sprod LK. Case Study: Unfavorable But Transient Physiological Changes During Contest Preparation in a Drug-Free Male Bodybuilder. Int J Sport Nutr Exerc Metab, 2017; 27: 550-559

Pasiakos SM, Vislocky LM, Carbone JW, Altieri N, Konopelski K, Freake HC, Anderson JM, Ferrando AA, Wolfe RR, Rodriguez NR. Acute energy deprivation affects skeletal muscle protein synthesis and associated intracellular signaling proteins in physically active adults. J Nutr, 2010; 140: 745-51

Pennings B, Groen BB, van Dijk JW, de Lange A, Kiskini A, Kuklinski M, Senden JM, van Loon LJ. Minced beef is more rapidly digested and absorbed than beef steak, resulting in greater postprandial protein retention in older men. Am J Clin Nutr, 2013; 98: 121-8

Peos JJ, Norton LE, Helms ER, Galpin AJ, Fournier P. Intermittent Dieting: Theoretical Considerations for the Athlete. Sports (Basel), 2019; 7 
Perez-Guisado J, Jakeman PM. Citrulline malate enhances athletic anaerobic performance and relieves muscle soreness. J Strength Cond Res, 2010; 24: 1215-22

Perrigue MM, Drewnowski A, Wang CY, Neuhouser ML. Higher Eating Frequency Does Not Decrease Appetite in Healthy Adults. J Nutr, 2016; 146: 59-64

Petrizzo J, DiMenna FJ, Martins K, Wygand J, Otto RM. Case Study: The Effect of 32 Weeks of Figure-Contest Preparation on a Self-Proclaimed Drug-Free Female's Lean Body and Bone Mass. Int J Sport Nutr Exerc Metab, 2017; 27: 543-549

Pontzer H , Durazo-Arvizu R, Dugas LR, Plange-Rhule J, Bovet P, Forrester TE, Lambert EV, Cooper RS, Schoeller DA, Luke A. Constrained Total Energy Expenditure and Metabolic Adaptation to Physical Activity in Adult Humans. Curr Biol, 2016; 26: 410-7

Ravussin E, Lillioja S, Anderson TE, Christin L, Bogardus C. Determinants of 24-hour energy expenditure in man. Methods and results using a respiratory chamber. J Clin Invest, 1986; 78: 1568-78

Raynor HA, Goff MR, Poole SA, Chen G. Eating Frequency, Food Intake, and Weight: A Systematic Review of Human and Animal Experimental Studies. Front Nutr, 2015; 2: 38

Res PT, Groen B, Pennings B, Beelen M, Wallis GA, Gijsen AP, Senden JM, van Loon LJ. Protein ingestion before sleep improves postexercise overnight recovery. Med Sci Sports Exerc, 2012; 44: 150-9

Rieu I, Balage M, Sornet C, Giraudet C, Pujos E, Grizard J, Mosoni L, Dardevet D. Leucine supplementation improves muscle protein synthesis in elderly men independently of hyperaminoacidaemia. J Physiol, 2006; 575: 305-15

Roberts J, Zinchenko A, Mahbubani K, Johnstone J, Smith L, Merzbach V, Blacutt M, Banderas O, Villasenor L, Varvik FT, Henselmans M. Satiating Effect of High Protein Diets on Resistance-Trained Subjects in Energy Deficit. Nutrients, 2018; 11

Robinson SL, Lambeth-Mansell A, Gillibrand G, Smith-Ryan AE, Bannock L. A nutrition and conditioning intervention for natural bodybuilding contest preparation: case study. J Int Soc Sports Nutr, 2015; 12: 20

Rogacz S, Williams GH, Hollenberg NK. Time course of enhanced adrenal responsiveness to angiotensin on a low salt diet. Hypertension, 1990; 15: 376-80

Rohrig BJ, Pettitt RW, Pettitt CD, Kanzenbach TL. Psychophysiological Tracking of a Female Physique Competitor through Competition Preparation. Int J Exerc Sci, 2017; 10: 301-311

Rolls BJ, Castellanos VH, Halford JC, Kilara A, Panyam D, Pelkman CL, Smith GP, Thorwart ML. Volume of food consumed affects satiety in men. Am J Clin Nutr, 1998; 67: 1170-7

Rossow LM, Fukuda DH, Fahs DA, Loenneke JP, Stout JR. Natural bodybuilding competition preparation and recovery: a 12-month case study. Int J Sports Physiol Perform, 2013; 8: 582-92

Saarni SE, Rissanen A, Sarna S, Koskenvuo M, Kaprio J. Weight cycling of athletes and subsequent weight gain in middleage. Int J Obes (Lond), 2006; 30: 1639-44

Sallinen J, Pakarinen A, Ahtiainen J, Kraemer WJ, Volek JS, Hakkinen K. Relationship between diet and serum anabolic hormone responses to heavy-resistance exercise in men. Int J Sports Med, 2004; 25: 627-33

Schoenfeld BJ, Aragon AA. How much protein can the body use in a single meal for muscle-building? Implications for daily protein distribution. J Int Soc Sports Nutr, 2018; 15: 10

Schoenfeld BJ, Aragon AA, Krieger JW. The effect of protein timing on muscle strength and hypertrophy: a meta-analysis. J Int Soc Sports Nutr, 2013; 10: 53

Schoenfeld BJ, Aragon AA, Krieger JW. Effects of meal frequency on weight loss and body composition: a meta-analysis. Nutr Rev, 2015; 73: 69-82

Schultz SG, Curran PF. Coupled transport of sodium and organic solutes. Physiol Rev, 1970; 50: 637-718

Schwedhelm E, Maas R, Freese R, Jung D, Lukacs Z, Jambrecina A, Spickler W, Schulze F, Boger RH. Pharmacokinetic and pharmacodynamic properties of oral L-citrulline and L-arginine: impact on nitric oxide metabolism. Br J Clin Pharmacol, 2008; 65: 51-9

Shafran R, Fairburn CG, Robinson P, Lask B. Body checking and its avoidance in eating disorders. Int J Eat Disord, 2004; 35: 93-101

Shafran R, Lee M, Payne E, Fairburn CG. An experimental analysis of body checking. Behav Res Ther, 2007; 45: $113-21$ 
Shearin EN, Russ MJ, Hull JW, Clarkin JF, Smith GP. Construct validity of the Three-Factor Eating Questionnaire: flexible and rigid control subscales. Int J Eat Disord, 1994; 16: 187-98

Shephard RJ. Electrolyte manipulation in female body-builders. Br J Sports Med, 1994; 28: 60-1

Simpson CC, Mazzeo SE. Calorie counting and fitness tracking technology: Associations with eating disorder symptomatology. Eat Behav, 2017; 26: 89-92

Slater G, Phillips SM. Nutrition guidelines for strength sports: sprinting, weightlifting, throwing events, and bodybuilding. J Sports Sci, 2011; 29 Suppl 1: S67-77

Smith CF, Williamson DA, Bray GA, Ryan DH. Flexible vs. Rigid dieting strategies: relationship with adverse behavioral outcomes. Appetite, 1999; 32: 295-305

Smith LW, Smith JD, Criswell DS. Involvement of nitric oxide synthase in skeletal muscle adaptation to chronic overload. J Appl Physiol (1985), 2002; 92: 2005-11

Spendlove J, Mitchell L, Gifford J, Hackett D, Slater G, CobleyS, O'Connor H. Dietary Intake of Competitive Bodybuilders. Sports Med, 2015; 45: 1041-63

Stachenfeld NS. Acute effects of sodium ingestion on thirst and cardiovascular function. Curr Sports Med Rep, 2008; 7: S7-13

Steen SN. Precontest strategies of a male bodybuilder. Int J Sport Nutr, 1991; 1: 69-78

Steinberg DM, Tate DF, Bennett GG, Ennett S, Samuel-Hodge C, Ward DS. Daily self-weighing and adverse psychological outcomes: a randomized controlled trial. Am J Prev Med, 2014; 46: 24-9

Stokes TA, Hector J, Morton RW, McGlory C, Phillips SM. Recent Perspectives Regarding the Role of Dietary Protein for the Promotion of Muscle Hypertrophy with Resistance Exercise Training. Nutrients, 2018; 10

Suryanarayana BV, Kent JR, Meister L, Parlow AF. Pituitary-gonadal axis during prolonged total starvation in obese men. Am J Clin Nutr, 1969; 22: 767-70

Teixeira PJ, Silva MN, Coutinho SR, Palmeira AL, Mata J, Vieira PN, Carraca EV, Santos TC, Sardinha LB. Mediators of weight loss and weight loss maintenance in middle-aged women. Obesity (Silver Spring), 2010; 18: 725-35

Tesch PA, Colliander EB, Kaiser P. Muscle metabolism during intense, heavy-resistance exercise. Eur J Appl Physiol Occup Physiol, 1986; 55: 362-6

Tillin NA, Moudy S, Nourse KM, Tyler CJ. Nitrate Supplement Benefits Contractile Forces in Fatigued but Not Unfatigued Muscle. Med Sci Sports Exerc, 2018; 50: 2122-2131

Timko CA, Perone J. Rigid and flexible control of eating behavior in a college population. Eat Behav, 2005; 6: $119-25$

Tinsley GM, Trexler ET, Smith-Ryan AE, Paoli A, Graybeal AJ, Campbell B, Schoenfeld BJ. Changes in Body Composition and Neuromuscular Performance Through Preparation, 2 Competitions, and a Recovery Period in an Experienced Female Physique Athlete. J Strength Cond Res, 2019; 33: 1823-1839

Tipton KD, Ferrando AA, Phillips SM, Doyle D, Wolfe RR. Postexercise net protein synthesis in human muscle from orally administered amino acids. Am J Physiol, 1999; 276: E628-34

Trexler ET, Hirsch KR, Campbell B, Smith-Ryan AE. Physiological Changes Following Competition in Male and Female Physique Athletes: A Pilot Study. Int J Sport Nutr Exerc Metab, 2017; 27: 458-466

Trexler ET, Persky AM, Ryan ED, Schwartz TA, Stoner L, Smith-Ryan AE. Acute Effects of Citrulline Supplementation on High-Intensity Strength and Power Performance: A Systematic Review and Meta-Analysis. Sports Med, 2019; 49: 707-718

Trexler ET, Smith-Ryan AE, Stout JR, Hoffman JR, Wilborn CD, Sale C, Kreider R, Jager R, Earnest CP, Bannock L, Campbell B, Kalman D, Ziegenfuss TN, Antonio J. International society of sports nutrition position stand: Beta-Alanine. J Int Soc Sports Nutr, 2015; 12: 30

Trommelen J, Kouw IW, Holwerda AM, Snijders T, Halson SL, Rollo I, Verdijk LB, van Loon LJ. 'Presleep dietary protein-derived amino acids are incorporated in myofibrillar protein during postexercise overnight recovery. Am J Physiol Endocrinol Metab, 2018; 314: E457-E467

Tylka TL, Calogero TM, Danielsdottir S. Is intuitive eating the same as flexible dietary control? Their links to each other and well-being could provide an answer. Appetite, 2015; 95: 166-75

Tylka TL, Kroon Van Diest AM. The Intuitive Eating Scale-2: item refinement and psychometric evaluation with college women and men. J Couns Psychol, 2013; 60: 137-53 
Volek JS, Freidenreich FJ, Saenz C, Kunces LJ, Creighton BC, Bartley JM, Davitt PM, Munoz PX, Anderson JM, Maresh CM, Lee EC, Schuenke MD, Aerni G, Kraemer WJ, Phinney SD. Metabolic characteristics of keto-adapted ultra-endurance runners. Metabolism, 2016; 65: 100-10

Volek JS, Kraemer WJ, Bush JA, Incledon T, Boetes M. Testosterone and cortisol in relationship to dietary nutrients and resistance exercise. J Appl Physiol (1985), 1997; 82: 49-54

Walberg JL, Johnston CS. Menstrual function and eating behavior in female recreational weight lifters and competitive body builders. Med Sci Sports Exerc, 1991; 23: 30-6

Walberg JL, Leidy MK, Sturgill DJ, Hinkle DE, Ritchey SJ, Sebolt DR. Macronutrient content of a hypoenergy diet affects nitrogen retention and muscle function in weight lifters. Int J Sports Med, 1988; 9: 261-6

Walberg-Rankin J, Edmonds CE, Gwazdauskas FC. Diet and weight changes of female bodybuilders before and after competition. Int J Sport Nutr, 1993; 3: 87-102

Wasserman DH. Four grams of glucose. Am J Physiol Endocrinol Metab, 2009; 296: E11-21

Weigle DS, Sande KJ, Iverius PH, Monsen ER, Brunzell JD. Weight loss leads to a marked decrease in nonresting energy expenditure in ambulatory human subjects. Metabolism, 1988; 37: 930-6

Westenhoefer J, Engel D, Holst C, Lorenz J, Peacock M, Stubbs J, Whybrow S, Raats M. Cognitive and weightrelated correlates of flexible and rigid restrained eating behaviour. Eat Behav, 2013; 14: 69-72

Westenhoefer J, Stunkard AJ, Pudel V. Validation of the flexible and rigid control dimensions of dietary restraint. Int J Eat Disord, 1999; 26: 53-64

Weyer C, Pratley RE, Salbe AD, Bogardus C, Ravussin E, Tataranni PA. Energy expenditure, fat oxidation, and body weight regulation: a study of metabolic adaptation to long-term weight change. J Clin Endocrinol Metab, 2000; 85: 1087-94

Witard OC, Jackman SR, Breen L, Smith K, Selby A, Tipton KD. Myofibrillar muscle protein synthesis rates subsequent to a meal in response to increasing doses of whey protein at rest and after resistance exercise. Am J Clin Nutr, 2014; 99: 86-95

Zhang Z, Venn BJ, Monro J, Mishra S. Subjective Satiety Following Meals Incorporating Rice, Pasta and Potato. Nutrients, 2018; 10; 11

\section{Corresponding author:}

Brandon Roberts, PhD, CSCS

The Strength Guys, Birmingham, AL, 35205

E-mail: robertsb21@gmail.com 